\title{
Household Attitudes Toward Energy Conservation in the Pacific Northwest: Overview and Comparisons
}

\author{
J. M. Fang
}

June 1985

Prepared for

Bonneville Power Administration

Office of Conservation under a Related Services Agreement

with the U.S. Department of Energy

Contract DE-AC06-76RLO 1830

Pacific Northwest Laboratory

Operated for the U.S. Department of Energy

by Battelle Memorial Institute 


\title{
DISCLAIMER
}

This report was prepared as an account of work sponsored by an agency of the United States Government. Neither the United States Government nor any agency thereof, nor any of their employees, makes any warranty, express or implied, or assumes any legal liability or responsibility for the accuracy, completeness, or usefulness of any information, apparatus, product, or process disclosed, or represents that its use would not infringe privately owned rights. Reference herein to any specific commercial product, process, or service by trade name, trademark, manufacturer, or otherwise, does not necessarily constitute or imply its endorsement, recommendation, or favoring by the United States Government or any agency thereof. The views and opinions of authors expressed herein do not necessarily state or reflect those of the United States Government or any agency thereof.

\author{
PACIFIC NORTHWEST LABORATORY \\ operated by \\ BATTELLE \\ for the \\ UNITED STATES DEPARTMENT OF ENERGY \\ under Contract DE-AC06-76RLO 1830
}

\begin{tabular}{|c|c|}
\hline \multicolumn{2}{|c|}{ Printed in the United States of America } \\
\hline \multirow{2}{*}{\multicolumn{2}{|c|}{$\begin{array}{c}\text { Available from } \\
\text { National Technical Information Service }\end{array}$}} \\
\hline & \\
\hline \multirow{3}{*}{\multicolumn{2}{|c|}{$\begin{array}{c}\text { United States Department of Commerce } \\
5285 \text { Port Royal Road } \\
\text { Springfield, Virginia } 22161\end{array}$}} \\
\hline & \\
\hline & \\
\hline \multirow{2}{*}{\multicolumn{2}{|c|}{$\begin{array}{l}\text { NTIS Price Codes } \\
\text { Microfiche A01 }\end{array}$}} \\
\hline & \\
\hline \multicolumn{2}{|c|}{ Printed Copy } \\
\hline & \\
\hline Pages & Codes \\
\hline $001-025$ & A02 \\
\hline 026-050 & $\mathrm{A03}$ \\
\hline 051-075 & AO4 \\
\hline $076-100$ & A05 \\
\hline $101-125$ & A06 \\
\hline $126-150$ & A07 \\
\hline $151-175$ & A08 \\
\hline $176-200$ & $A 09$ \\
\hline $201-225$ & A010 \\
\hline $226-250$ & A011 \\
\hline $251-275$ & A012 \\
\hline $276-300$ & A013 \\
\hline
\end{tabular}




\section{3}

PNL-5405

UC-95d

HOUSEHOLD ATTITUDES TOWARD

ENERGY CONSERVATION

IN THE PACIFIC NORTHWEST:

OVERVIEW AND COMPARISONS

J. M. Fang

June 1985

Prepared for Bonneville Power Administration Office of Conservation under a Related Services Agreement with the U.S. Department of Energy Contract DE-AC06-76RLO 1830

Pacific Northwest Laboratory Richland, Washington 99352 


\section{SUMMARY}

This report presents an overview of a baseline residential energy conservation study for the Pacific Northwest conducted in November 1983 by RMH Research, Inc. for Pacific Northwest Laboratory and the Bonneville Power Administration (the RMH study). It also compares the study results with available data from other surveys to help identify inconsistencies and to provide a better perspective for interpreting and using the RMH study results.

The primary focus of the RMH study is conservation marketing. As such it assesses the attitudes, perceptions, and past conservation actions of the region's residents and provides market segmentation based upon past conservation actions and the propensity to invest in conservation in the future. Excluding renters, who account for about 24 percent of the region's households, three prospect groups for marketing conservation investments are identified:

- First Tier Prospects are those who are very likely to invest in additional conservation measures requiring larger sums of money. It is estimated that this group accounts for about 547,000 households, or 18 percent of the region's households.

- Second Tier Prospects are those who are somewhat likely to invest in full weatherization. It is estimated that this group accounts for about 22 percent of the region's households or 695,700 .

- Non-Prospects are those who are unlikely to invest in energy conservation in the near future. The number of households in this group is estimated to be $1,113,400$ or 36 percent of the regional total.

A summary comparison of the most important distinguishing attributes of the three prospect groups is presented. Considering the current surplus status of the region's electricity supply situation and the overall strategy in capability building, implications include 1) using public information programs through utilities and the news media to maintain the conservation interests of the first-tier prospects and 2) exploring ways to move the second-tier 
prospects into the first tier and to reach the su-called non-prospect group and the rental housing market.

Among the energy institutions in the region, the local utility is the most well known, the most favorably regarded, and the most trusted as a source of energy information. The believability rating of the media is also relatively high; it is second only to the local utility. It follows that both the local utility and the media should be tapped for the purpose of marketing conservation.

The RMH study compares the general public's conservation views with their views as perceived by the conservation infrastructure - those who are responsible for the design and implementation of conservation programs or those who are in a position to influence the funding of conservation programs. Generally, the infrastructure's perceptions of the general public's responses are much more likely to disagree with the public's own responses than to agree. Where the two did not match, it was more likely for the infrastructure to think that the general public was less conservation oriented than the public's own perceptions. The implication is that, rather than relying primarily on their own perceptions of the public's views, those who are designing and implementing conservation programs may want to conduct appropriate surveys and studies to gauge household attitudes, interests, and opinions.

To the extent that results from other studies are available for comparison, they are generally consistent with the RMH results. Therefore, with due consideration of the nature and limitations, the RMH results can be appropriately applied to conservation planning and marketing purposes. 


\section{ABBREV IATIONS}

$\begin{array}{ll}\text { BPA } & \text { Bonneville Power Administration } \\ \text { ODOE } & \text { Oregon Department of Energy } \\ \text { NPPC } & \text { Northwest Power Planning Council } \\ \text { PNL } & \text { Pacific Northwest Laboratory } \\ \text { PNW } & \text { Pacific Northwest } \\ \text { PNWRES } & \text { Pacific Northwest Residential Energy Survey } \\ \text { RMH } & \text { RMH Research, Inc. } \\ \text { WPPSS } & \text { Washington Public Power Supply System } \\ \text { WRDC } & \text { Western Rural Development Center }\end{array}$




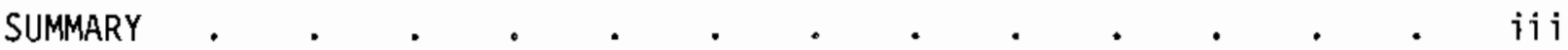

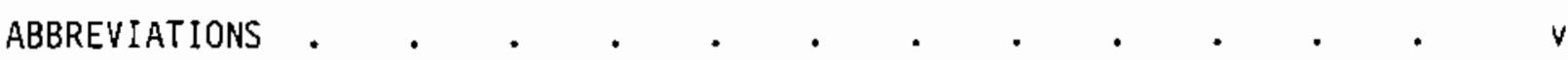

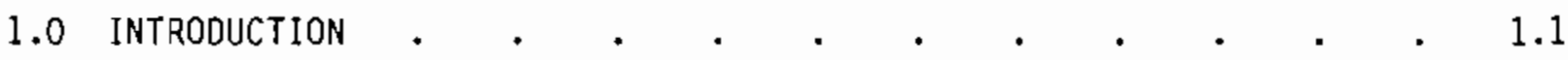

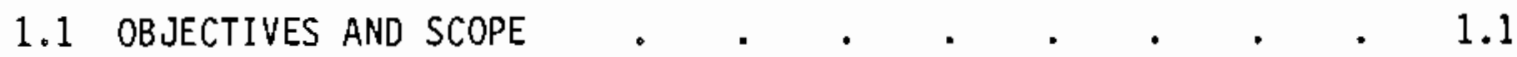

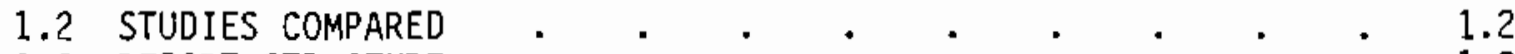

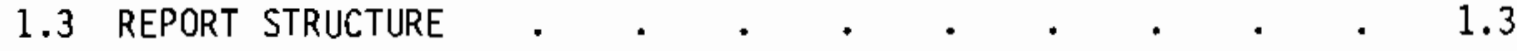

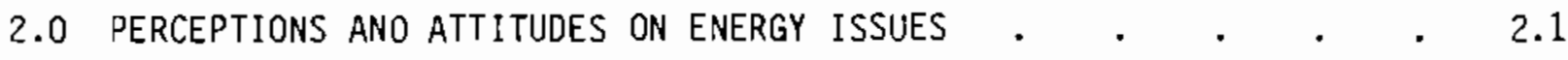

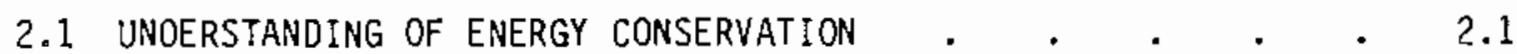

2.2 CONCERN ABOUT ENERGY CONSERVATION AND OTHER ISSUES $\quad \cdot \quad \cdot \quad .1$

2.3 SERIOUSNESS OF THE ENERGY SITUATION $. \quad \cdot \quad . \quad . \quad \cdot \quad \cdot 2.2$

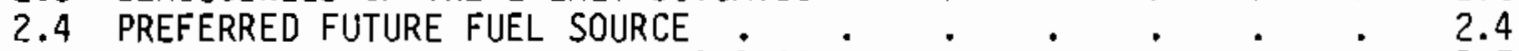

2.5 SEgMENTATION BY ATTITUOE TOWARO CONSERVATION.$\quad \cdot \quad \cdot \quad \cdot \quad \cdot \quad \cdot \quad$

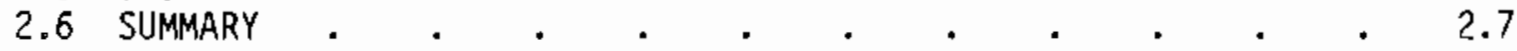

3.0 ENERGY CONSERVATION ACTIONS, INVESTMENT, AND FINANCING . $\quad$ • 3.1

3.1 ENERGY CONSERVATION ACTIONS . . . . . . . . . . . . . . 3.1

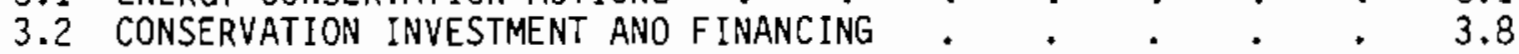

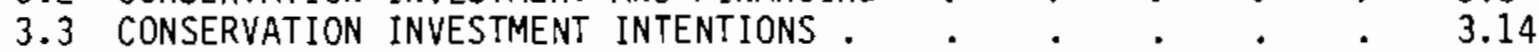

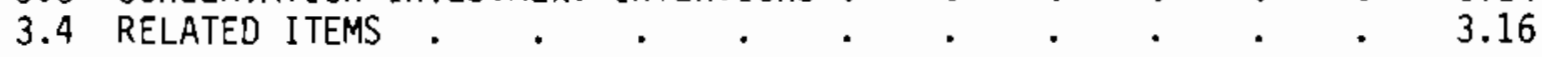

3.4.1 Impacts of Past Conservation Actions . . . . 3.16

3.4.2 Satisfaction with Past Conservation Actions . . $\quad 3.16$

3.4.3 Decision-Makers in Energy Conservation . . $\quad 3.17$

3.4.4 Preferred Methods of Conserving Energy . . . 3.17

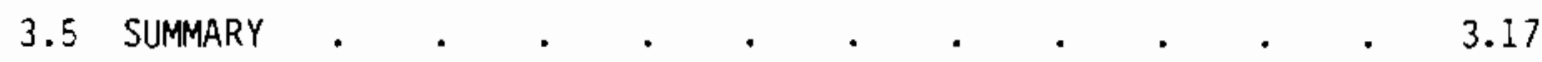

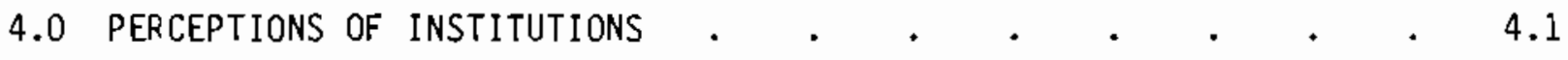

4.1 RESPONSIBILITY IN SETTING ELECTRIC RATES . . . . . 4.1

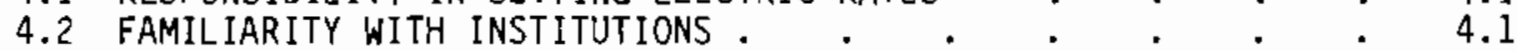

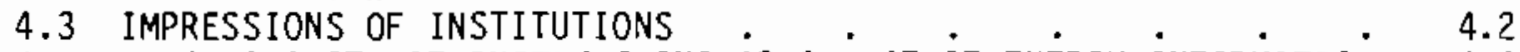

4.4 BELIEVABILITY OF INSTITUTIONS AS SOURCE OF ENERGY INFORMATION 4.2

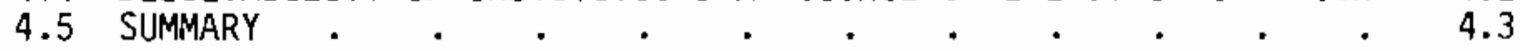

5.0 TARGET PROSPECTS OF CONSERVATION INVESTMENTS . $. \quad . \quad$. 5.1

6.0 RESPONSIVENESS OF CONSERVATION INVESTMENT TO PERCEIVED RETURN $\quad$ • 6.1

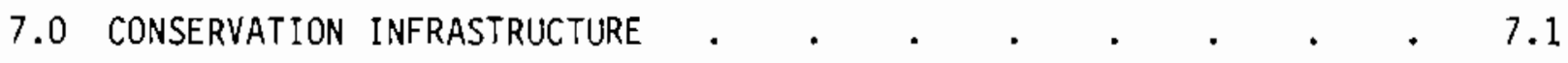

7.1 PERCEPTIONS AND ATTITUDES ON CONSERVATION AND ENERGY ISSUES . 7.1

7.2 ENERGY CONSERVATION ACTIONS, INVESTMENT, AND FINANCING . $\quad 7.5$ 
7.3 PERCEPTION OF INSTITUTIONS

7.4 RESPONSIVENESS OF CONSERVATION INVESTMENT TO PERCEIVED RETURN 7.9

7.5 SUMMARY

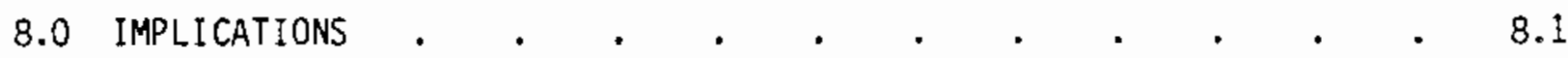

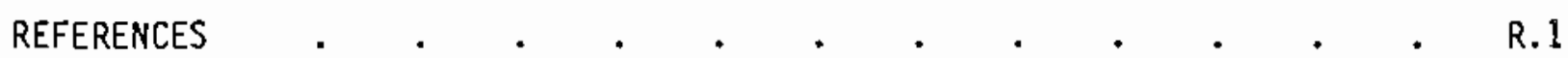

APPENDIX A: DETAILED SUPPORTING TABLES FOR FIGURE 3.1 . $\quad$ • . . $\quad$ A.1

APPENDIX B: INFORMATION DN RENTERS AND RENTAL UNITS . $\quad . \quad$ • $\quad$ B. 1 


\section{FIGURES}

3.1 Trends of Saturation Ratios in Selected Items of Conservation Investment: Wall Insulation, Weatherproofing, Thermal Pane or Storm Windows, Storm Doors, Wood Stoves, and Clock Thermostat Setbacks; by State

\section{TABLES}

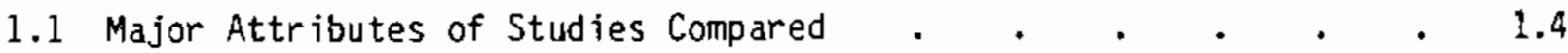

2.1 Seriousness of Current Energy Situation . . . . . . . . 2.3

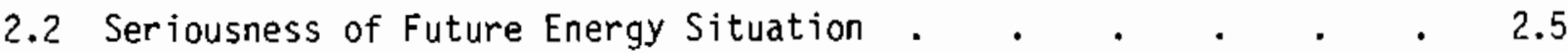

2.3 Preference and Opposition to Future Energy Source from the Western Rural Development Center Results . . . . . . . . . 2.6

3.1 Penetration Rates of "Added Insulation" in the Pacific Northwest, by State . . . . . . . . . . . . . . 3.6

3.2 Average Amount Spent on Improving Home Energy Efficiency per

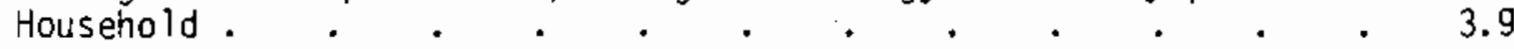

3.3 Financing Investment in Home Energy Efficiency: Proportions of Homeowners Who Have Made Efficiency Improvements . . . .

3.4 Energy Conservation Intentions: Respondents Who Had Not Invested in the Conservation Item Indicated but Planned to Invest, as

Percentage of All Respondents . . . . . . . . . . 3.15

4.1 Believability of Institutions as Source of Energy Information . 4.4

5.1 Comparison of Conservation Target Prospect Groups . . . . 5.3

7.1 Percent of People Agreeing With the Statement $\quad$. . . . 7.4

7.2 Comparison of Infrastructure Perceptions With Resident (Claimed) Actual Conservation Actions . . . . . . . . . 7.6

7.3 Sources of Conservation Investment Financing . $\quad$. 7.7

7.4 Future Energy Conservation Improvements . . . . . . . . . 7.7

7.5 Believability of Energy Conservation Information Disseminated by Specific Sources

7.6 Likelihood of Investing $\$ 15$ and $\$ 25$ Per Month to Save a Specific Amount Per Month 
A.1 Proportions of Homes with Insulation in Outside Walls in the Pacific Northwest, by State . . . . . . . . A.2

A.2 Proportions of Homes with Weatherproofing (Weatherstripping and Caulking) in the Pacific Northwest, by State. . . . A.4

A.3 Proportions of Homes with Thermal Pane or Storm Windows in the Pacific Northwest, by State . . . . . . . A.6

A.4 Proportions of Homes with Storm or Insulated Doors in the Pacific Northwest, by State . . . . . . . . . . . A.8

A.5 Proportions of Homes with Wood Stoves in the Pacific Northwest, by State

A.6 Proportions of Homes with Clock Thermostat Setback in the Pacific Northwest, by State. . . . . . . . . . 


\subsection{INTRODUCTION}

During 1983-84, Pacific Northwest Laboratory (PNL) managed a baseline residential energy conservation marketing study for the Bonneville Power Administration (BPA) as part of an Analysis of the Marketing Environment for BPA Conservation Activities Project. In the study, telephone interviews with a total of 2,000 residents from throughout the Pacific North-west were conducted by RMH Research, Inc, of River Edge, New Jersey. The study results are documented in a report entitled The Marketing Environment for Energy Conservation in the Pacific Northwest (RMH Research, Inc. 1984 a \& b).

The RMH study represents the first comprehensive region-wide study of the marketing aspects of energy conservation in the Pacific Northwest. It covers consumers' attitudes, perceptions, and awareness of energy conservation; the actions they claimed to have taken; the way they financed their past conservation investments; their perceptions of energy institutions; the consumers' behaviors with respect to newspapers, radio and television broadcasts; and the responsiveness of conservation investment to perceived returns by households. It also contains data on the so-called conservation infrastructure, those who design and implement conservation programs or who make decisions concerning conservation funding.

\subsection{OBUECTIVES AND SCDPE}

There are two objectives in this report: (1) to present an overview of the RMH study results on a topical basis; and (2) to compare, to the extent possible, the RMH results with those from other surveys. ${ }^{1}$ The comparison is to help identify inconsistencies among the surveys and to provide a better perspective in interpreting the results of the studies. From BPA's

1 At the same time as the baseline residential conservation study was conducted, a companion study on the marketing environment for solar and heat pump water heaters was also conducted by RMH, Inc. However, the present report concentrates exclusively on the baseline survey. For information concerning the water heater study, please refer to the report entitled The Marketing Environment for Solar and Heat Pump Water Heaters (RMH Research, Inc. 1984c). 
perspective, if the results from the different surveys are found to be largely comparable with one another, there would be greater confidence in applying the results for various purposes, such as conservation marketing, planning, modeling, and load forecasting.

In presenting the overveiw, the emphasis is on those items for which comparable data from other surveys are available. ${ }^{2}$ However, some RMH study results, for which no comparable data are available, are important and represent unique contributions of the RMH study. These results are summarized without the comparison.

\subsection{STUDIES COMPARED}

The studies from which revelent data points are derived for comparison with the RMH results are the following: ${ }^{3}$

- Oregon Residential Energy Survey conducted by Oregon Department of Energy (OOOE 1983)

- Energy Directions for the United States: A Western Perspective conducted by the land grant universities in ten western states (Western Rural Development Center (WRDC) 1982)

- Baseline Energy Survey conducted for the Northwest Power Planning Council (The Council)(Northwest Attitudes and Social Research, Inc. 1982)

- 1979 Pacific Northwest Residential Energy Survey (PNWRES 79) conducted for BPA by Elrick \& Lavidge, Inc. (1980).

2 The RMH study included recomendations from the conservation marketing perspective. Since this report focuses on suminary and comparison of results, the recommendation portion of the RMH report is not included.

3 The 1983 Pacific Northwest Residential Energy Survey conducted for BPA by Louis Harris, Inc. has not yet been formally published as yet. Hence it is not included in this comparison. 
The 1983 Oregon Department of Energy study contains some results from a study conducted in 1979. Therefore, 1979 Oregon data are also used in the comparison.

Table 1.1 provides information on some important characteristics of the studies compared, including geographical coverage and divisions, time survey conducted, sample size, survey format, and whether or not energy conservation was the primary emphasis of the study.

\subsection{REPORT STRUCTURE}

This report is organized on a topical format. For each topic, the RMH results are first sumarized and then compared with other survey results. Chapter 2 discusses the results of general consumer perceptions and attitudes on conservation and energy issues. Chapter 3 covers energy conservation actions, investment and financing. Chapter 4 treats perceptions of institutions. Chapter 5 presents RMH's market segmentation results. Chapter 6 discusses the results on responsiveness of conservation investment to perceived returns. Chapter 7 explains the results on perceptions of conservation infrastructure. Chapter 8 then discusses the implications of the study findings.

Appendix A presents detailed supporting information on the proportions of houses in the region equipped with certain energy conservation measures. Appendix. B sumarizes information from the RMH study on renters and rental units. 
TABLE 1.1. Major Attributes of Studies Compared

\begin{tabular}{|c|c|c|c|c|c|}
\hline Study/Survey & $\begin{array}{c}\text { RMH } \\
\text { Study }\end{array}$ & $\begin{array}{l}\text { Energy } \\
\text { Survey" }\end{array}$ & $\begin{array}{l}\text { "Western } \\
\text { Perspectives" }\end{array}$ & $\begin{array}{l}\text { PNWRES } \\
79 / 80\end{array}$ & OREGON \\
\hline Prepared by: & $\begin{array}{l}\text { RMH Research, } \\
\text { Inc. }\end{array}$ & $\begin{array}{l}\text { NW Attitudes } \\
\text { and Social } \\
\text { Research lnc. }\end{array}$ & $\begin{array}{l}\text { Western Rural } \\
\text { Development } \\
\text { Center in cooper- } \\
\text { ation with land } \\
\text { grant Universities }\end{array}$ & $\begin{array}{l}\text { Elrick and } \\
\text { Lavidge, } \\
\text { Inc. }\end{array}$ & $\overline{O D O E}$ \\
\hline Prepared for: & PNL and $B P A$ & $\begin{array}{l}\text { Northwest } \\
\text { Power plan- } \\
\text { ning Council }\end{array}$ & WRDC & $\overline{\mathrm{BPA}}$ & $\overline{\mathrm{DDOE}}$ \\
\hline $\begin{array}{l}\text { Geographical } \\
\text { Coverage and } \\
\text { Division }\end{array}$ & $\begin{array}{l}\text { Pacific NW; } \\
\text { Division by } \\
\text { Weather zone } \\
\text { and by special } \\
\text { divisions }\end{array}$ & $\begin{array}{l}\text { Pacific NW; } \\
\text { by State }\end{array}$ & $\begin{array}{l}\text { The U.S. Western } \\
\text { States including } \\
\text { AZ, CA, CO, ID, } \\
\text { MT, NY, OR, UT, } \\
\text { WA, WY, and PA; by } \\
\text { State and by Rural- } \\
\text { Urban division }\end{array}$ & $\begin{array}{l}\text { Pacific NW } \\
\text { by State and } \\
\text { by Weather } \\
\text { zone }\end{array}$ & $\begin{array}{l}\text { Oregon } \\
\text { only }\end{array}$ \\
\hline $\begin{array}{l}\text { Time Survey/ } \\
\text { Study } \\
\text { conducted }\end{array}$ & $\begin{array}{l}\text { November/ } \\
\text { December } 1983\end{array}$ & February 1982 & March/April 1981 & $\begin{array}{l}\text { October } 1979 \\
\text { through } \\
\text { January } 1980\end{array}$ & $\begin{array}{l}\text { August } \\
1982\end{array}$ \\
\hline Sampie Size & $\bar{z}, 0 \overline{0}$ & $60 \overline{6}$ & $\begin{array}{l}9,763 \text { total; } \\
3,553 \text { for ID, MT, } \\
0 R \text {, and WA }\end{array}$ & $4,030^{x}$ & 697 \\
\hline Survey format & $\begin{array}{l}\text { Telephone } \\
\text { Interview }\end{array}$ & $\begin{array}{l}\text { Telephone } \\
\text { Interview }\end{array}$ & $\begin{array}{l}\text { Mailed } \\
\text { Questionnaire }\end{array}$ & $\begin{array}{l}\text { In-person } \\
\text { Intervicw }\end{array}$ & $\begin{array}{l}\text { Mailed } \\
\text { Question- } \\
\text { natre for } \\
\text { 1982 data } \\
\text { ln-person } \\
\text { Interview } \\
\text { for } 1979 \\
\text { data }\end{array}$ \\
\hline $\begin{array}{l}\text { Emphasis on } \\
\text { Energy Conser- } \\
\text { vation } \\
\text { Attitudes and } \\
\text { Actions }\end{array}$ & $\begin{array}{l}\text { The primary } \\
\text { Emphasis }\end{array}$ & $\begin{array}{l}\text { No; only a part } \\
\text { of overall } \\
\text { attitudes } \\
\text { survey }\end{array}$ & $\begin{array}{l}\text { Yes; a major } \\
\text { emphasis of the } \\
\text { study }\end{array}$ & $\begin{array}{l}\text { No; the } \\
\text { primary } \\
\text { emphasis } \\
\text { is on } \\
\text { physical } \\
\text { character- } \\
\text { istics of } \\
\text { building } \\
\text { stock }\end{array}$ & $\begin{array}{l}\text { Yes: the } \\
\text { major } \\
\text { emphasis }\end{array}$ \\
\hline
\end{tabular}




\subsection{PERCEPTIONS AND ATTITUDES ON ENERGY ISSUES}

This chapter presents the results of the RMH study on Pacific Northwest residents' perceptions and attitudes on energy conservation and related issues. Specifically, the public's understanding of and concern about energy conservation, their views about the seriousness of the energy situation, and the segmentation of the respondents by their attitudes toward conservation are presented. Some comparisons with other survey results are also made.

\subsection{UNDERSTANDING OF ENERGY CONSERVATION}

A large majority of residents in the Pacific Northwest interpreted energy conservation in a general manner. When asked to explain the meaning of energy conservation, 74 percent responded with "conserving or saving energy":

$\begin{array}{lr}\text { conserve/save energy } & 74 \% * \\ \text { specific conservation actions } & 37 \% \\ \text { save money } & 19 \% \\ \text { use or develop alternative energy sources } & 8 \% \\ \text { social responsibility/way of life } & 8 \% \\ \text { other } & 3 \%\end{array}$

* multiple mentions included

While geographical divisions within the region did not affect these perceptions in any significant manner, income, education and age did have some impact. Residents with higher income and more education tended to define energy conservation in more general terms (saving energy), while people with lower income were more likely to mention specific actions.

These results appeared to be generally comparable to those from the 1982 Power Council survey. In this earlier survey, 93 percent of the respondents indicated that they had heard the term energy conservation, and 78 percent were able to define energy conservation.

\subsection{CONCERN ABOUT ENERGY CONSERVATION AND OTHER ISSUES}

Although people in the region were concerned about energy conservation, the intensity of this concern was lower than that of concerns for crime, cost 
of energy, inflation, unemployment, and envirorment. When asked to indicate their concern on various issues, 48 percent of the respondents chose "very concerned" for energy conservation and energy use in the home. The corresponding proportions were, in sequence, $7 t$ percent for crime, 70 percent for the cost of energy, 64 percent for inflation, 63 percent for unemployment, and 55 percent for environment.

In contrast, 31 percent of the respondents in the 1982 Power Council survey picked unemployment as the most important problem facing the Pacific Northwest in the next 5-10 years. The difference between the results of the 1982 Power Council Survey and the RMH survey, which was conducted in late 1983, may reflect that the economic recovery had affected the general public's out look on the employment situation.

\subsection{SERIOUSNESS OF THE ENERGY SITUATION}

A large majority of the respondents in the RMH study felt that the U.S. energy situation in late 1983 was serious: 30 percent believed that it was "very serious;" 51 percent chose "somewhat serious;" 12 percent "not very serious," and 3 percent "not serious at all." Four percent said that they did not know or gave no answer. Table 2.1 shows that these results are generally consistent with the 1981 results in Idaho, Oregon, Washington, and Montana. Note, however, that the proportion of respondents indicating "very serious" was somewhat lower in the RMH survey in 1983 than the 1981 results. This may be partially attributed to the electricity supply surplus for the Pacific Northwest that had become more widely known by 1983 compared to 1981.

When the question is focused specifically to the Northwest energy supply situation, as contained in 1982 Power Council survey, the group indicating "very serious" is much smaller at 16 percent, compared to a 30 percent to 40 percent range when the focus is the much broader "U.S. energy situation." To a large extent, the difference may be attributed to the widespread discussion of electricity surplus for the Pacific Northwest that was being reported often in the news during late 1983.

The RMH results also showed that, overa 11,80 percent of the respondents felt that, five years hence, the U.S. energy situation would be as serious or more serious than it was in November 1983. The 1982 Council survey showed that 
TABLE. 2.1. Seriousne!ss of Current Energy Situation

\begin{tabular}{|c|c|c|c|c|}
\hline nata Source & RMII & Pover Councia & $\begin{array}{l}\text { Western Rural } \\
\text { Development Center }\end{array}$ & \\
\hline $\begin{array}{l}\text { Area } \\
\text { Applicable nate }\end{array}$ & $\begin{array}{l}\text { PNW } \\
\text { Nov. } 1983\end{array}$ & Feb. 1982 & $\begin{array}{l}\text { Oregon } \\
\text { Early 1981 }\end{array}$ & Montana \\
\hline
\end{tabular}

Percent nf Respondents Kegarding the Energy Situation as:

$\begin{array}{lccccc}\text { Very Serious } & 30 & 15 & 40 & 39 & 34 \\ \begin{array}{l}\text { Serious, Somewhat } \\ \text { Serious, Not } \\ \text { Very Serious }\end{array} & 63 & 74 & 55 & 60 & 61 \\ \text { Not Serious At All } & 3 & 7 & 5 & 3 & 3 \\ \text { Non't Know/No Answer } & 4 & 3 & 0 & 0\end{array}$

\section{Data Sources}

RMH: RMH Research, Inc. 1984 Table 7, p. 20

Power Council: Northwest Attitudes and Sncial Research, Inc. 1982 Table 4, p. 6

WRDC: Western Rural Development Center 1982 Table 38, p. 85

\section{Questions Asked}

RMił: "How serious would you say the energy situation is in the United States today - would you say it is very serious, sompwhat serious, not very serious, or not serious at all!"

Power council: "In your opinion, is the energy supply situation in the Horthwest very serious, somewhat serious not so seriaus, or not at all serious!"

Western Rural nevelopment Ceriter: "Some people feel that energy is a serious national problem, but the other people feel it is not. We would like to know your opinion. Do you consider meeting the United States energy needs during the next ten to twenty years to be: (please circle number of your opinion)
1. Not a serious problem
2. A somewhat serious problem
3. A serious problem
4. A very serious problem 
72 percent of the respondents believed that the Pacific Northwest energy supply situation would either be as serious or worsen in ten years from 1982.

Comparison between the results from the RMH survey and the Power Council showed that the region's residents were more pessimistic about the intermediate future energy situation for the U.S. as a whole than for the region alone. Seven of 10 respondents in the RMH survey, compared to about 4 of 10 in the Power Council survey, picked the "more serious" or "worsen" category (Table 2.2). Again, this difference in energy situation out ook could reflect the residents' realization that there is an electricity supply surplus situation for the new term in the Pacific Northwest.

\subsection{PREFERRED FUTURE FUEL SOURCE}

When asked to rank a list of future energy sources according to their preferences, 66 percent of the respondents selected solar energy as their first and second choices, compared to 45 percent for hydropower, 24 percent for nuclear energy, 23 percent for energy conservation. The other three sources were natural gas (17 percent), coal (13 percent) and oil (3 percent). Conversely, nuciear energy had the highest proportion as the last choice (30 percent), compared to 22 percent for coal. The proportions for last choice for the other sources were in the 6 percent to 9 percent range.

The result of generally favorable views concerning solar, wind, hydropower, and energy conservation and less favorable views on coal and nuclear power is generally consistent with the Power Council 1982 survey and the 1981 survey by WRDC. In the Power Council survey, 8 or 9 of 10 people would like to see more of solar, wind and conservation used in the region and 1 of 2 would like to see more of hydroelectric power used. For coal, while 1 in 3 people were in favor of using more, an equal proportion were in favor of using less. Only 28 percent of the respondent: would like to see more of nuclear energy used; 52 percent would like to see less. As shown in Table 2.3, the Western Rural Development Center results have approximately the same pattern. There was much stronger support for solar and wind energy and weaker support for nuclear power and coal. 
TABLE 2.2 Seriousness of Future Energy Situation

$\begin{gathered}\text { RMH } \\ \text { froars } \\ \text { from now }\end{gathered}$
Percent Responding $(\%)^{(d)}$

Much or Somewhat

more serious

69

38

Same

11

34

Somewhat or Much

less serious

15

23

Not Sure/No Answer

6

5

Data Sources

RMH: RMH Research 1984 Table 9a, p. 23

Power Council: Northwest Attitudes and Social Research, Inc, 1982, p. 7

Questions Asked

RMH: "From what you may have heard or read, and no matter how serious you believe the energy situation is NOW, how serious do you think it will be in five years from now -- do you think it will be much more serious, somewhat more serious, somewhat less serious or much less serious than it is NOW?"

Power Council: "Do you think the energy supply situation in the region will improve or worsen in the next 10 years?"

Footrote

(a) Percent of Respondents regarding future energy situations, as compared to present situation. 
TABLE 2.3 Preference and 0pposition to Future Energy Source from the Western Rural Development Center Results

\begin{tabular}{|c|c|c|c|c|c|c|c|c|}
\hline & \multicolumn{2}{|c|}{ Idaho } & \multicolumn{2}{|c|}{ Oregon } & \multicolumn{2}{|c|}{ Washington } & \multicolumn{2}{|c|}{ Montana } \\
\hline & $\frac{\overline{\text { Favor }}}{(\%)}$ & $\frac{0 \text { pposed }}{(\%)}$ & $\frac{\overline{\text { Favor }}}{(\%)}$ & $\frac{\text { opposed }}{(\%)}$ & $\frac{\text { Favor }}{(\%)}$ & $\frac{\text { opposed }}{\left(\begin{array}{l}(\%) \\
\%\end{array}\right)}$ & 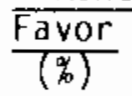 & $\frac{\text { opposed }}{(\%)}$ \\
\hline More use of solar energy & 93 & 2 & 93 & 1 & 92 & 1 & 93 & 1 \\
\hline More use of wind energy & 88 & 1 & 93 & 1 & 89 & ] & 93 & 1 \\
\hline $\begin{array}{l}\text { Reduced energy use in } \\
\text { Home } \\
\text { Business \& Industries } \\
\text { Individual travel } \\
\text { Agriculture }\end{array}$ & $\begin{array}{l}70 \\
51 \\
53 \\
18\end{array}$ & $\begin{array}{l}14 \\
23 \\
25 \\
60\end{array}$ & $\begin{array}{l}78 \\
52 \\
53 \\
17\end{array}$ & $\begin{array}{l}13 \\
22 \\
25 \\
57\end{array}$ & $\begin{array}{r}73 \\
60 \\
54 \\
6\end{array}$ & $\begin{array}{l}11 \\
19 \\
22 \\
53\end{array}$ & $\begin{array}{l}64 \\
54 \\
55 \\
20\end{array}$ & $\begin{array}{l}17 \\
21 \\
23 \\
59\end{array}$ \\
\hline More use of nuclear power & 51 & 29 & 41 & 36 & 43 & 36 & 44 & 34 \\
\hline More use of western coal & 69 & 10 & 62 & 12 & 64 & 9 & 75 & 10 \\
\hline
\end{tabular}

Source: Western Rural Development Center 1982 Tables 37-41,43,46 and 47, pp. 87-93, 96 and 97. 


\subsection{SEGMENTATION BY ATTITUDE TOWARD CONSERVATION}

Judged from the two most-frequently-agreed-with statements concerning energy conservation, the attitude of the region's residents toward energy conservation appeared to be a mixture of materialistic considerations and a feeling of social responsibility. Approximately three of four people agreed that "most people who conserve electricity do so to save money." Similarly, about the same proportion of the region's residents agreed with the statement that "it's our responsibility to conserve electricity for future generations."

Based upon responses to ten statements concerning energy conservation, the RMH study segmented residents in the Pacific Northwest into the following groupings :

- Cynics $(9 \%)$ : people who were doubters or were skeptical of the value of conservation efforts

- Altruists (33\%): residents who felt strong social responsibility

o Disheartened (22\%): those who felt they had done everything possible to save energy or were totally satisfied with what they had done

- Not classified (36\%): people whose attitudinal characteristics did not quite fit any of the above three categories.

The cynics and the disheartened offered 1 imited opportunity for future energy conservation action. The altruists, mainly comprised of younger or higher income residents, offered the most promising opportunities for marketing energy conservation.

\subsection{SUMMARY}

The above discussion on the perceptions and attitudes on energy issues by residents of the Pacific Northwest can be summarized below:

- Seven of ten residents in the region defined energy conservation broadly as conserving or saving energy in gentral or specific fuel type. One in three interpreted it as adopting specific energy conservation actions. About one in five equated energy conservation to saving money. Less than one in ten thought energy conservation to be using or developing alternative energy sources or a social responsibility. 
- Although residents in the Pacific Northwest were concerned about energy conservation and energy use in the home, it appeared that, in late 1983, the intensity of this concern was not as strong as the concern for crime, cost of energy, inflation, unemployment, and the environment.

- A large majority of area residents (8 of 10) felt that the U.S. energy situation was serious as of 1983 and would be at least as serious five years hence.

- Solar energy was the most preferred future energy source. It was followed by hydropower, nuclear energy, energy conservation, natural gas, coal, and oil. Nuclear power and coal were the two sources chosen by the largest proportion of the respondents as the leas: preferred source.

- Attitudinally, there was a large segment of area residents (over 3 of 10 ) who felt strongly that conserving energy was a social responsibility. In contrast, only one of ten doubted or was skeptical about the value of energy conservation. Two of ten felt tha: they had done what they could or were satisfied with what they had done in the area of conservation. The other four of ten did not quite fit into any of the above three groups.

These results are generally consistent with the results from surveys conducted for the Power Council in 1982 and by WRDC in 1981. However, the following two points are worth noting:

o The proportion of the population who regarded the U.S. energy situation as "very serious" seemed to have fallen a bit from about 39 percent in 1981 to 30 percent in 1983. Moreover, if the verm were phrased in terms of "energy supply situation in the Pacific Northwest," the proportion of people who would regard it as "very serious" was even lower, less than 2 in 10. This difference can probably be attributed to the perception that the region has a electricity supply surplus.

o In early 1982, unemployment was picked as the most important problem to the area residents. By late 1983, the proportion picling the unemployment issue as the most serious concern was somewhat smaller than those picking crime and the cost of energy. The economic recovery that started in 1982 had probably contributed to this change in perception. 


\subsection{ENERGY CONSERVATION ACTIONS, INVESTMENT, AND FINANCING}

This chapter presents the results of the RMH study on past conservation actions, amount of conservation investment, methods of financing the investment, and conservation intentions ( $p$ lanned investment). In each of these areas, the RMH results are compared with appropriate data from other studies. Related results on perceived impacts of past conservation investment, satisfaction on past conservation measures installed, decision-makers of past conservation actions, and preferred methods of conserving energy are also briefly noted.

\subsection{ENERGY CONSERVATION ACTIONS}

The proportions of residents in the region claiming to regularly practice some type of no-cost/low-cost conservation actions were high. When asked to indicate specific conservation practices they "have done or regulariy follow," the following results are given:

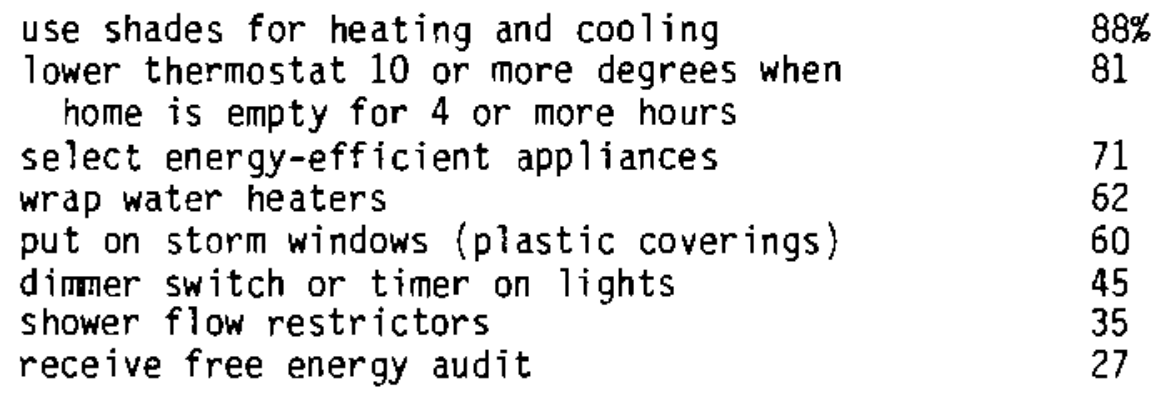

The portions of those who claimed to have spent money on energy conservation items are also high, although somewhat lower than those for nocost/low-cost items. The items and the proportions of residents indicating that they have "paid for material and/or labor to have item installed in the house" are as follows:

$\begin{array}{ll}\text { insulate roof or attic } & 77 \% \\ \text { weatherproofing } & 71 \\ \text { thermal pane or storm windows } & 67 \\ \text { wood stove/furnace } & 65 \\ \text { insulate outside walls } & 64 \\ \text { storm or insulated doors } & 63\end{array}$


insulate basement or crawlspace

automatic or clock thermostat setback 29

heat pump

sun space or passive solar

solar panel for space heating

In attempting to make consistent comparison of the above results with available survey data, the proper interpretation of the above results becomes an issue because of the way the questions were stated:

"I will read you a few specific energy conservation measures. Please tell me which of these conservation practices you have done or regularly follow."

"Have you paid for material and/or labor to have (item from list) installed in your home?"1

In both cases, there is a lack of specific time period in the question. In the first case, the term "have done or regularly follow" can cover a wide range of situations. It is conceivable that a respondent could have done it only once and still answer yes. In the second case, the most plausible interpretation would be the time period between the time when the respondent moved into the house and the time the interview was conducted. An extreme case would be to interpret the results of the question in the same manner as if the question "Is your home currently equipped with the following energy conservation improvement" were asked. Appendix Tables A.1 through A.6 treat the RMH results in this extreme case and compare them with available data from other surveys on wall insulation, weatherproofing (weatherstripping and caulking), thermal pane or storm windows, storm or insulated doors, use of wood stoves, and installation of clock thermostat setback. ${ }^{2}$ The other surveys

1 This is question $7 \mathrm{a}$ in the survey instrument. However, throughout the text of the RMH report, a differently phrased question is cited: "Is your home currently equipped with the following energy conservation improvements?" Telephone conversations with Bob Weiss, of RMH Research, verified that the question in the questionnaire is the correct one.

2 Comparisons of other items are also possible. However, because of the sinall numbers of common data points, the results are much less interesting. 
included in the comparison are those done by Western Rural Development Center for 10 western states, the 1980 PNWRES study for BPA, and the Oregon Department of Energy's 1982 survey.

Figure 3.1 depicts the general results of the Tables A.1 through A.6. Keeping in mind the diverse nature of the separate surveys, the following observations seem appropriate:

- Although the data points were from different sources and collected using different survey methods and instruments, the results appear to be fairly consistent with one another ${ }^{3}$ and depict an upward trend. Corollarily, it might be argued that the interpretation of RMH results as indications of "homes equipped" might be appropriate in a sense.

- Since Idaho and Montana are more subject to weather extremes than Oregon and Washington, the proportions of homes with insulation in the walls, weatherproofing, storm doors and windows, and the use of wood stoves in these two inland states are higher than the two coastal states.

- The saturation ratios of the clock thermostat setback controls appear to be relatively low compared to the other conservation items included.

It should be noted that the above comparison treats the RMH results as measuring the saturation ratios ${ }^{4}-$-which is an extreme case. It should also be noted that the upward trends of the saturation ratios compared cannot be regarded as entirely the result of conservation action and retrofitting by residents. Due to changes of local energy codes, new houses are built with more energy-efficiency features. As the proportions of newer houses become

3 However, some inconsistencies do show up in the data. In Figure 3.1, these inconsistencies appear as declines in the saturation rates.

4 Treating the RMH results in this manner is necessitated by the fact that other data points in the comparison are saturation ratios. Saturation ratios are the proportion of total homes with a certain conservation measure at any given point in time. In contrast, penetration rates are the ratios of the additional homes with a certain conservation measures over net increases in the total stock of homes over a period of time, such as a year. 


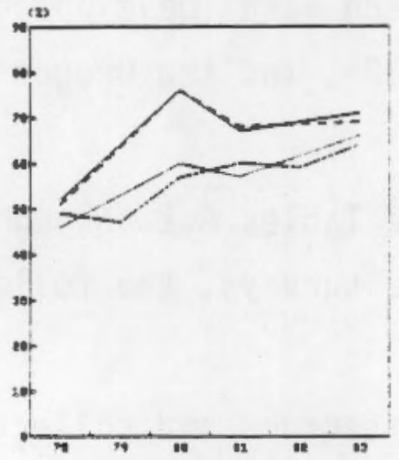

(a) Wall Insulation

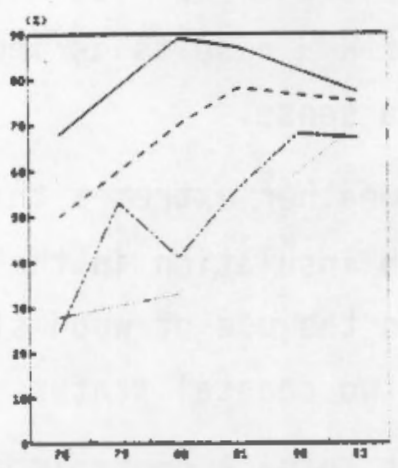

(e) Thermal Pane or Storm Hindows

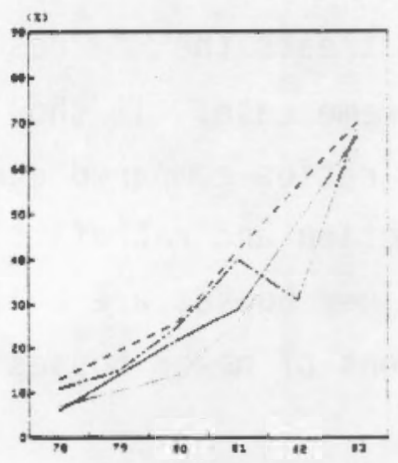

(e) Hood Stoves

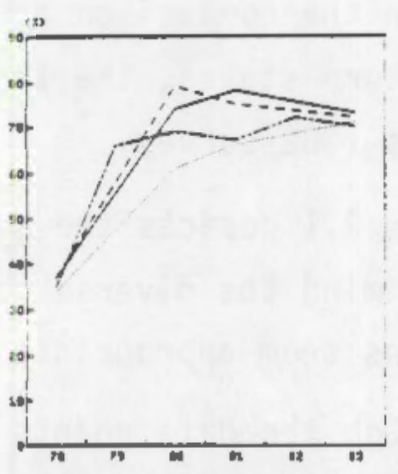

(b) Weatherproofing

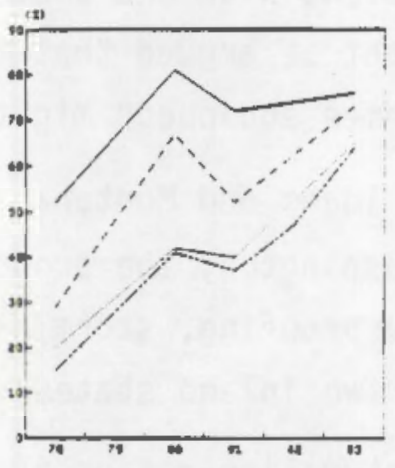

(d) Storm Doors

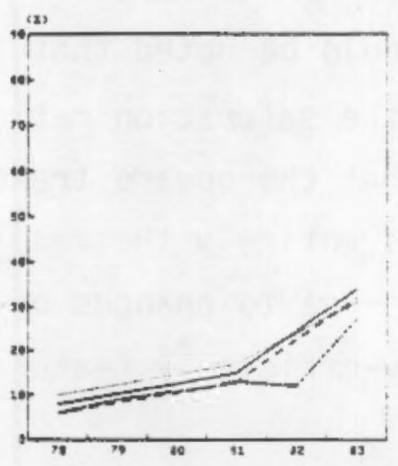

(f) Clock Thermostat Setzack

FIGURE 3.1. Trends of Saturation Ratios in Selected Items of Conservation Investment: Wall Insulation, Weatherproofing, Thermal Pane or Storm Windows, Storm Doors, Wood Stoves, and Clock Thermostat Setbacks; by State

Sources: See Appendix A 
larger, the saturation of important energy-efficiency features becomes higher. This would tend to raise the saturation ratios shown in Figure 3.1 .

Another interpretation of the RMH results on conservation actions is to treat them as the actions taken by the respondents since they moved into their homes up to November 1983, when they responded to the survey. When treated in this manner, it becomes possible to make comparisons of penetration rates. Unfortunately, due to the differences in wording of the various surveys, consistent data for such comparisons are more difficult to compile than in the case of saturation ratios.

Table 3.1 presents available data on "added insulation" from the studies by Western Rural Development Center, Northwest Power Planning Council, Oregon Department of Energy, and RMH. To properly understand the results of the comparison, differences in the time periods, geographical coverage and coverage in the action items need to be noted:

- Time period of action taken: The WROC data measure the penetration rates during the time the respondents moved into the home up to early 1981. The Power Council study measures the penetration during 1980-81. The Oregon Department of Energy data cover approximately the 12-month period prior to August 1982. The RMH results cover the period between moving-in up to November 1983 .

- Geographical coverage: The Western Rural Development Center study presents data for the individual states of Idaho, Dregon, Washington and Montana, without aggregation to a Pacific Northwest region. The Power Countil data show only the Pacific Northwest region as a whole. ODOE data are specific to Oregon only. The RMH data cover both the individual states and the region, although the datum for Montana is only for Western Montana, while the datum for Montana from the WRDC study is for all of the state of Montana.

- Coverage of conservation action: While the WRDC, ODOE, and RMH studies have separate "penetration rates" of added insulation in the wall, ceiling, or floor, the Power Council study used only the aggregated term "added insulation" without providing details of the individual items.

Given the above considerations, the RMH results could be interpreted as the "cumulative effects" of the other three results (for Oregon) or two results 
TABLE 3.1. Penetration Rates of "Added Insulation" in the Pacific Northwest, by State

$(\%)$

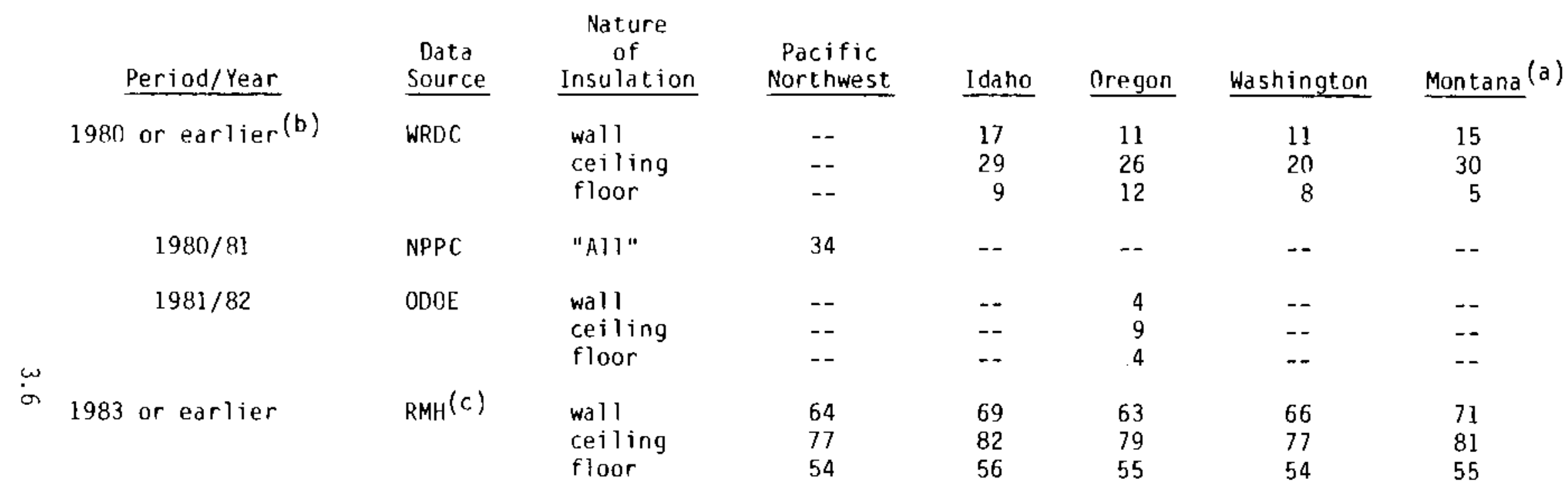

\section{Data Sources}

WRDC: Western Rural Development Center 1982. Tables 67, 68, 69; pp. $119-121$. NPPC: Northwest Attitudes and Social Research 1982. Table 12, p. 18.

ODOE: Oregon Department of Energy 1983, p. 18.

RMH: RMH Research, Inc. 1984a. Table 32, p. 32. 
TABLE 3.1 (cont.)

\section{Question Asked}

WRDC: "Listed below are certain energy saving features that might be added to your home (by you or if you rent, your landlord). For each item, please circle the one best answer:

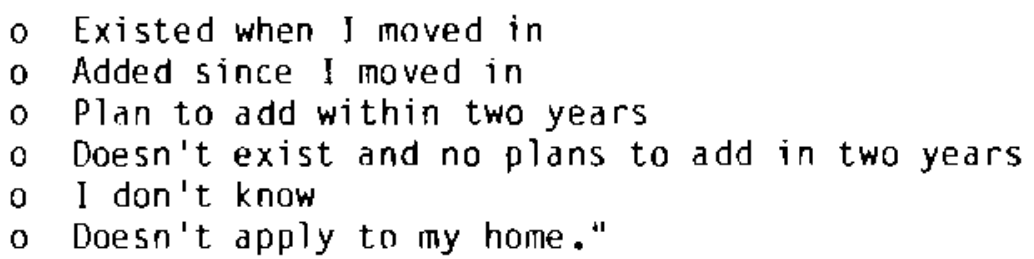

NPPC: "What actions have you done to conserve energy?"

ODOE: "In the past 12 months, have any of the following items been installed in your current. residence?"

RMH: "Have you paid for material and/or labor to have (item from list) installed in your home?"

\section{Footnotes}

(d) For Montana, the RMH figures cover only Western Montana while the WRDC figures cover all Montana.

(b) Strictly speaking, the period should be between the time when the respondent moved into the house and early 1981. The term "1980 or earlier" is used for brevity.

(c) The RMH figures used four geographical regions: Northwest (NW), Southwest (SW), Northeast (NE) and Southeast (SE). Washington State figure was derived from simple average of NW and NE. Oregon value was derived from simple average of SW and SE. Idaho value was calculated from simple average of NE and SE. Montana value is assigned from NE. 
(for other states). The "cumulative penetration rates" in the RMH study are larger than the sum of the other three studies (for Oregon) or two studies (for other states and the region).

In summary, the above discussion shows that:

- In examining and comparing survey results, it is important to review the wording of individual questions asked of the respondents. Attention should be given to distinguishing the time period covered, the geographical coverage, and the nature of the specific items covered.

- In examining conservation actions, it is important to distinguish between "saturation ratios" of a conservation measure in total stock and "penetration rates" of a conservation measure over one or two years. The latter, penetration rates, is incremental to the former, saturation ratios, and therefore is more consistent with "conservation action taken" for a given period.

0 When, in the extreme, the RMH results on conservation action are treated as saturation ratios, there is an upward trend in the saturation ratios for wall insulation, weatherproofing, thermal pane or storm windows, storm doors, wood stoves, and clock thermostat setbacks.

- In the example of "added insulation," in a genera? sense, the RMH results could be interpreted as the "cumulative saturation rates" of the WRDC, Power Council, and ODOE (for Oregon only) over the period in question. At the very least, this interpretation is not inconsistent with the available data.

\subsection{CONSERVATION INVESTMENT AND FINANCING}

The RMH study results indicate that those home owners in the region who claimed to have invested in energy efficiency improvements said they have spent, on the average, approximately $\$ 1800$ per household during 1981-83. As shown in Table 3.2, this appears to be somewhat less than the amount claimed to have been spent during the previous three years (1978-80). However, this comparison should be tempered with the following considerations: 
TABLE 3.2. Average Amount Spent on Improving Home Energy Efficiency per Household

(\$)

\begin{tabular}{lll} 
& $\begin{array}{c}1978-80 \\
\text { WROC }\end{array}$ & $\begin{array}{c}1981-83 \\
\text { RMH }\end{array}$ \\
\cline { 2 - 3 } & $2186^{(b)}$ & 1811 \\
Pacific Northwest & 2034 & 1769 \\
Idaho (a) & 1923 & 1668 \\
Mont and & 2533 & 1866 \\
Oregon & 2232 & 1752 \\
Washington & &
\end{tabular}

Data Sources: RMH Research 1984, Table 38, p. 88.

WRDC 1982, Table 12, p. 27. Simple sum of mean values for each of the three years.

Questions Asked

WRDC: "Thinking about the last three years (19781980), about how much money have you spent to improve the energy efficiency of your home (e.g., weatherstripping, insulation, set back thermostats, storm doors, solar equipment)? (If none, please put "D".)

$$
\begin{aligned}
& \$ \text { you spent in } 1978 ; \$ \text { you spent } \\
& \text { in 1979; \$_ you spent in 1980." }
\end{aligned}
$$

RMH: "In the past 3 years, approximately how much money did you spend on reducing the amount of energy used in your home?"

\section{Footnotes}

(a) For Montana, the RMH figures cover on ly western Montana while the WRDC figures cover all Montana.

(b) Simple average of four states.

(c) The RMH figures used four geographical regions: Northwest (NW), Southwest (SW), Northeast (NE) and Southeast (SE). Washington State figure was derived from simple average of NW and NE. Oregon value was derived from simple average of $S W$ and $S E$. Idaho value was calculated from simple average of NE and $\mathrm{SE}$. Montana value is assigned from NE. 
- The RMH study asked for an estimate of the lump sum for the three years together, while the WRDC study asked for estimates of individual years.

o The RMH study was a telephone survey with a limited amount of time for responding to a question, whereas the WRDC study is a mailed questionnaire survey. Although the mailed survey allowed more time for individual respondents to ponder the question and consult their records, it does not necessarily follow that the respondents would actually consult their records.

How were the above conservation investments financed? The RMH study suggests that respondents claimed that the investments were most often financed by using money from current income (75 percent) and money from savings (38 percent). The next sources of funds were cutting back other purchases (27 percent) and delaying other purchases (21 percent). About one in four homeowners having invested in improving home energy efficiency used tax credits. Only about one in five used either loans from the local public utility or other loans and credits. In slightly less than one in 10 cases, the payments were "made by the utility".

The RMH results for 1981-83 are generally consistent with similar results of the four states for 1978-1980 from the Western Rural Development Center. Table 3.3 presents a comparison of the two survey results. The following can be noted:

- Both studies showed that money from current income was the most frequentiy mentioned source of investment funds. The second most frequently mentioned source of funds was money from savings.

- The WRDC result seemed to have a larger proportion of homeowners using tax credits (36-39 percent range compared to 22-24 percent range). Note that the WRDC specifically included both "Federal" and "state" tax credits, while the RMH study mentioned only the federal tax credits. Also note that the WRDC included the tax credit item in a separate question dealing exclusively with awareness and use of tax credits, while the RMH study included the tax credit as one of the items on the sources of funds.

- The RMH study contained one item, "payments made by utility," which was not included in the WRDC study. 
IABLE 3.3. Financing Investment in Home Energy Efficiency: Proportions of Homeowners who Have Made Efficiency Improvements

(क)

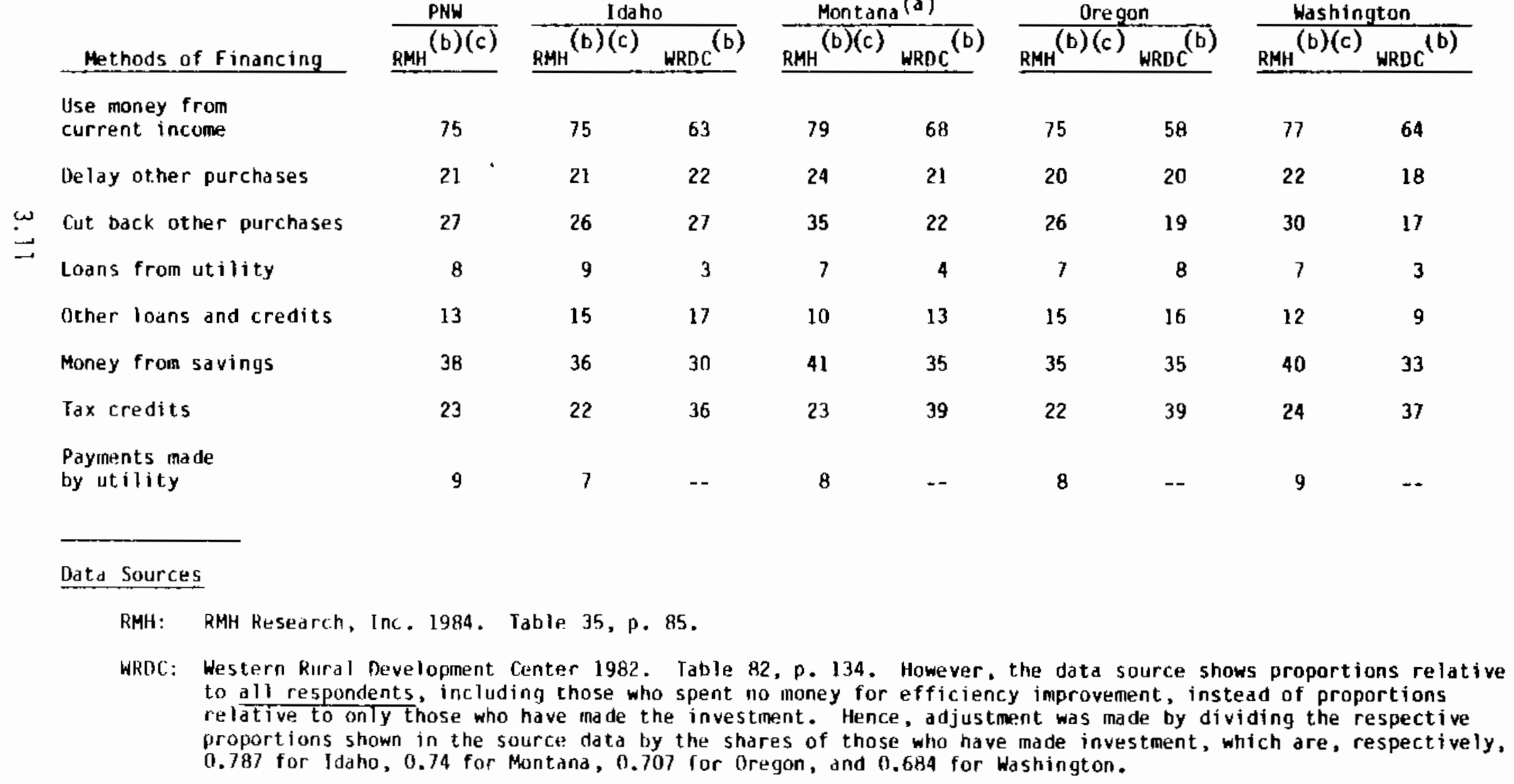


TABLE 3.3 (cont.)

\section{Questions Asked}

RMH: "How did you pay for the energy conservation investment improvements you made in your home in the past 2 or 3 years, did you (multiple record)
o use money from current income
- delay other purchases
o cut back on other purchases
- used loan from utility
- payment made by utility
o use other loan or credit
- use money from savings
o get tax credits from the Federal government
o other

WRDC: "In order to pay for any energy efficiency improvements made in your home from 1978 to 1980 , which did you do (please circle all that apply):

1. spent money on energy efficiency improvements
2. used money from current income
3. delayed other purchases
4. cut back on other purchases
5. used loan from utility company
6. used other loan or credits
7. used money from savings
8. other (write in)

WRDC: "In recent years, it has been possible to claim federal and, in some places, state tax benefits for improving the energy efficiency of one's home. Which best describe your awareness of these tax benefits? (Please circle the number of your answer in each column.) 
TABLE 3.3 (cont.)

$\begin{array}{cc}\begin{array}{c}\text { Federal Income } \\ \text { Tax Credit } \\ \text { (circle one) }\end{array} & \begin{array}{c}\text { State Income } \\ \text { Tax Credit } \\ \text { (circle one) }\end{array} \\ 1 & 1 \\ 2 & 2 \\ 3 & 3 \\ & 4\end{array}$

not aware of this benefit

awa re, but have made no claim

aware, and a claim made on 1978, 1979, or 1980 taxes

no tax benefit in my state

(If claim made) would you have probably made these improvements if the tax benefits had not been available?
1. Definitely no
2. Probably no
3. Probably yes
4. Definitely yes

\section{Footnotes}

(a) For Montana, the PNRES79/80 and RMH figures cover only Western Montana while the WROC figures cover all Montana.

(b) WRDC data are for 1978-1980; RMy data are for 1981-1983.

(c) The RMH figures used four geographical regions: Northwest (NW), Southwest (SW), Northeast (NE) and Southeast (SE). Washington State figure was derived from simple average of NW and NE. Oregon value was derived from simple average of SW and SE. Idaho value was calculated from simple average of NE and SE. Montana value is assigned from NE. 


\subsection{CONSERVATION INVESTMENT INTENTIONS}

The RMH study indicated that, among homeowners who had not invested in specific conservation measures, 6 to 14 percent of all homeowners would be very likely or somewhat likely to invest in measures over the next two or three years (1984-86). The specific measures and the associated proportions are shown below acording to the order of prevalence:

$\begin{array}{ll}\text { sun space (passive solar) } & 14 \% \\ \text { storm doors } & 13 \\ \text { heat pumps } & 12 \\ \text { solar panels for space heating } & 12 \\ \text { thermal pane or storm windows } & 11 \\ \text { clock thermostat setbacks } & 11 \\ \text { weatherproofing } & 10 \\ \text { floor insulation } & 9 \\ \text { wood stove/furnace } & 8 \\ \text { attic/ceiling insulation } & 6 \\ \text { wall insulation } & 6\end{array}$

Homeowners also speculated that their houses will be worth approximately $\$ 3000$ more after they complete future energy conservation improvements.

Table 3.4 compares the RMH results with data from the Western Rural Development Center. It shows that the proportions of the numbers of respondents who had not installed a specific conservation item and planned to install the item over all homeowners declined from 1981-82 to 1984-86 for weatherproofing and attic/ceiling insulation; rose for solar heating, clock thermostat setbacks, and wall insulation; and stayed about the same for storm doors, thermal pane/storm windows, floor insulation and wood stoves/furnaces. The following points would appear to be appropriate:

- From early 1981 to late 1983, the number of residents who claimed to be planning to make investments in jtems with relatively low saturation ratios appeared to have risen. Examples are solar heat and clock thermostat setbacks, for which the saturation ratios were 3 percent and 29 percent, respectively.

- In contrast, proportions of residents who clajmed to be planning to make investment in items with relatively high saturation ratios as a percentage of all homeowners appeared to have fallen. Examples are weatherproofing 
TABLE 3.4. Energy Conservation Intentions: Respondents Who Had Not Invested in the Conservation Item Indicated but Planned to Invest, as Percentage of All Respondents

$(\%)$

\begin{tabular}{|c|c|c|c|c|c|}
\hline Data Source & RMH & \multicolumn{3}{|c|}{ Western Rural Development } & Center \\
\hline $\begin{array}{l}\text { Applicable Period } \\
\text { Region/State }\end{array}$ & $\begin{array}{c}1984-86 \\
\text { PNW } \\
\end{array}$ & Idaho & Oregon & $\begin{array}{l}1981-82 \\
\text { Washington }\end{array}$ & Montana \\
\hline $\begin{array}{l}\text { Storm doors } \\
\text { Solar heating } \\
\text { Thermal pane or storm windows } \\
\text { Clock thermostat setbacks } \\
\text { Weatherproofing } \\
\text { Floor insulation } \\
\text { Wood stove/furnace } \\
\text { Attic/ceiling insulation } \\
\text { Wall insulation }\end{array}$ & $\begin{array}{r}13 \\
12 \\
11 \\
11 \\
10 \\
9 \\
8 \\
6 \\
6\end{array}$ & $\begin{array}{r}16.6 \\
6.5 \\
8.9 \\
6.1 \\
13.7 \\
9.4 \\
9.4 \\
8.1 \\
3.9\end{array}$ & $\begin{array}{r}13.2 \\
7.2 \\
13.7 \\
4.3 \\
13.4 \\
10.9 \\
9.3 \\
8.3 \\
4.1\end{array}$ & $\begin{array}{r}13.2 \\
4.4 \\
16.8 \\
6.2 \\
16.9 \\
9.4 \\
11.2 \\
9.6 \\
4.2\end{array}$ & $\begin{array}{r}9.1 \\
6.7 \\
4.9 \\
4.2 \\
10.0 \\
5.0 \\
8.1 \\
9.9 \\
5.8\end{array}$ \\
\hline
\end{tabular}

\section{Data Sources}

RMH: RMH Research, Inc. 1984. Table 40a, p. 94.

WRDC: Western Rural Development Center 1982. Table 9, p. 25.

\section{Questions Asked}

RMH: "How likely is it that you will spend money to install (item from list) within the next 2 or 3 years - would you say it is very likely, somewhat likely, not very likely or not at all likely?"

WRDC: "Listed below are certain energy saving features that might be added to your home (by you or if you rent, your 1 andlord). For each item, please circle the one best answer:

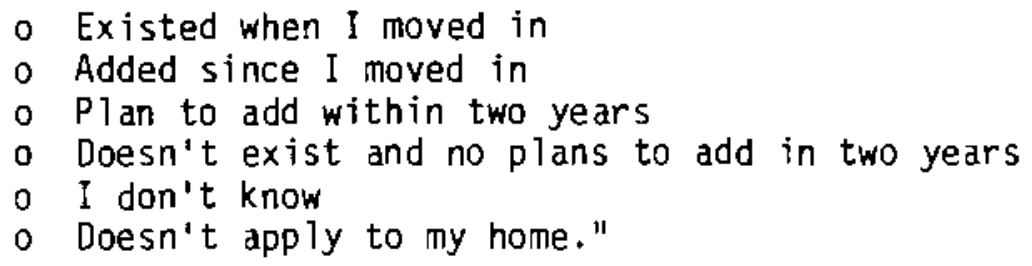


and attic/ceiling insulation, with saturation ratios of 71 percent and 77 percent, respectively.

- For those items with saturation ratios in the mid-range of 40 percent to 70 percent, the revealed intentions to invest seem to have been sustained during the 1981-83 period.

The above generalizations are subject to considerations of differences in data and geographical coverage, survey methodologies, dates survey taken and potential differences in interpretation noted eariier.

\subsection{RELATED ITEMS}

Other aspects of the RMH results related to conservation investment and decisions are briefly described in this section. These aspects include impact of, and satisfaction with, past conservation actions, decision-makers in household conservation actions, and preferred method of conserving energy. Because of lack of data, minimal comparison with results of other studies was made.

\subsubsection{Impacts of Past Conservation Actions}

Two monetary impacts of past conservation actions were quantified in the

RMH study. First, although only about one-half of the respondents were willing to guess at the amount of savings in energy expenditures resulting from the energy conservation actions taken, approximately two of three (66 percent) of those who gave an estimate claimed to have saved an average of over $\$ 100$ per year. The average amount of annual savings on utility bills was $\$ 380$. Second, respondents estimated that, as a result of past investment, the value of their homes increased, on the average, about $\$ 2900$.

\subsubsection{Satisfaction with Past Conservation Actions}

In the RMH study, respondents were asked to indicate whether they were dissatisfied with the conservation actions taken and investment made and, if dissatisfied, to indicate why. Almost all of those households that had made conservation investment were satisfied with those measures; only 4 percent expressed dissatisfaction. The areas of dissatisfaction concentrated on poor 
product quality, poor performance, and improper installation of storm windows and doors, insulation, and heating equipment.

\subsubsection{Decision-Makers in Energy Conservation}

40 percent of the time the decision to make conservation investment was made by the male head of the household. Similarly, 40 percent of the time, the decision was made jointly by the male and female heads of households. 20 percent of the time, the decision was made by the female head of the householit.

\subsubsection{Preferred Methods of Conserving Energy}

Given a choice between changing ways of living and spending money on energy efficiency improvements as a means of conserving energy, the RMH results suggest that 50 percent of the respondents chose to change their ways of living, while 31 percent preferred to spend money. 16 percent would do both. Those who preferred to change their ways of living were more likely to be the ones who regarded the U.S. energy situation as serious.

The WRDC study posed a different question with a broader scope. The respondents were asked to indicate whether, in order to meet future U.S. energy needs, they think the U.S. should depend on cutbacks in energy use, expanded energy production, or both. The results of the four states in the Pacific Northwest follow the general pattern below (Western Rura? Development Center 1982, Table 4, p. 19):

- Approximately 2 of 3 favored reliance on both cutbacks of energy use and increased energy production.

- About 1 of 5 chose increased energy production.

- Less than 1 of 10 chose cutbacks in energy use.

\subsection{SUMMARY}

A majority of households in the Pacific Northwest claimed to have taken no/low-cost energy conservation actions such as using shades for improving the efficiency of heating or cooling, turning down thermostat 10 or more degrees 
When homes were empty for 4 or more hours, selecting energy-efficient appliances, wrapping water heaters, and putting up plastic window covering. Anong energy conservation measures requiring substantial investment, a majority of households in the region also claimed to have added insulation to the roof or the attic, outside walls, and basement, performed weatherproofing, installed thermal pane or storm windows, wood stove or furnace, and storm doors.

Over the 2-3 years of 1981-83, the average investment in energy conservation was approximately $\$ 1800$ per household for those homeowners who claimed to have made such investments. An average savings in annual energy bills of about $\$ 380$ per household was claimed to have resulted from the investment. Those homeowners who said they had made conservation investments also guessed that the value of their home increased about $\$ 2900$ as a result of the investment made. Past conservation investments were generally financed through current income (75 percent), delay or cutback of other purchases (21 percent and 27 percent, respectively), savings (38 percent), tax credits (23 percent), utility loans or payments ( 8 percent), or regular loans or credits (13 percent). 9 percent of the respondants indicated that the payments for investment were paid by utilities. The overwhelming majority were satisfied with their conservation investment; only 4 percent expressed any dissatisfaction.

The proportions of those homeowners who said they had not invested in specific conservation measures but indicated that they were at least somewhat likely to invest in the future were in the range of 6 percent to 14 percent of all home owners, depending upon the specific conservation measure in question. These homeowners speculated that their home value would increase an average of about $\$ 3300$.after they completed installation of the specific conservation measures.

More people in the Pacific Northwest expressed a preference for changing their ways of living in order to conserve energy (50 percent), compared to spending money in making an investment ( 31 percent) or doing both (16 percent). The decision to take conservation actions was as often made by the male head of household as made by both male and female heads of household together ( 40 percent each). 
Comparison of the RMH study results with available data from other surveys leads to the following findings:

- Considering the wording of the questions regarding conservation actions taken, the results of the RMH study can be interpreted in two ways. When the RMH results are interpreted as measuring total saturation ratios of the various energy efficiency features in the home, available data depicted a general upward trend in the saturation ratios for wall insulation, weatherproofing, thermal pane or storm windows, storm doors, wood stoves, and thermostat setback controls. An alternative interpretation of the RMH results of conservation action is that they represented the "accumulated penetration rates" from the time the respondents moved into their houses and November 1983, when they responded to the interview.

- The $\$ 1800$ average conservation investment per household claimed to have been made during 1981-83 in the RMH study is somewhat less than the approximately $\$ 2200$ per household claimed to be made during 1978-80 in the WRDC study. However, because of differences in the manner in which these data were generated, the significance of the differences in investment can not be property determined.

- Allowing for multiple mentions, the most frequentiy cited source of funds for financing conservation investment is money from current income (60-80 percent). The second most frequently mentioned source is money from savings (30-40 percent). Tax credits are aiso important (20-40 percent). Other financing sources include cutting back on other purchases (20-30 percent), delaying other purchases (around 20 percent), other loans and credits (10-20 percent), and loans from utility or payments made by utility (less than 10 percent for each). This suggests that there is a relative aversion to incur debt for making conservation investment.

- To some extent, announced intentions to invest in energy efficiency appear to have fallen somewhat from early 1981 to late 1983 for weatherproofing and attic or ceiling insulation, probably due largely to relatively high saturation ratios. In contrast, solar heating and thermostat setback control, with relatively low saturation ratios, showed increases in 
intentions to invest. The intentions to invest stayed approximately the same during the period for other items whose saturation ratios are in the intermediate range. These measures include storm doors, therma? pane/storm windows, floor insulation, and wood stoves/furnaces. 


\subsection{PERCEPTIONS OF INSTITUTIONS}

This chapter describes findings on the perceptions of the region's residents concerning energy and non-energy related institutions in terms of knowledge of the electricity rate setting responsibility, familiarily, favorability, and believability as sources of energy information. Some results from the 1982 Northwest Power Council study are cited for comparison purposes.

\subsection{RESPONSIBILITY IN SETTING ELECTRIC RATES}

The RMH study inquired about the understanding of the region's residents as to which entity set the prices they paid for electricity. The results showed that 41 percent chose the local utility, 35 percent picked BPA, and 10 percent felt that both were responsible. The proportion of people who feit that BPA was responsible was higher for men (41 percent) than for women (30 percent). Higher income groups also had higher proportions than lower income groups of people who thought BPA was responsible (40 percent vs. 28 percent).

\subsection{FAMILIARITY WITH INSTITUTIONS}

The RMH study asked the respondents to indicate their impression about four institutions: the local utility, BPA, the Northwest Power Planning Council, and the state energy office. Some residents responded by picking the choice of "don't know enough to answer." The proportions not familiar with each of the four institutions were 12 percent for the local utility, 35 percent for BPA, 60 percent for the Northwest Power Planning Council, and 57 percent for the state energy office. It follows that the local utility was the most widely known. The second most widely known was BPA. The Northwest Power Planning Council and the state energy office had about the same degree of familiarity among the region's populace.

The above result concerning relative degree of people's familiarity with BPA and the Power Council is consistent with the 1982 result in the Power Council study. In this earlier study, respondents were asked if they had heard about BPA, Washington Public Power Supply System (WPPSS), Columbia River Intertribal Fisheries Commission, and the NPPC. Those who recognized the institutions were then asked to describe what the institution does. These 
descriptions were then reviewed to see if they were consistent with the actual roles of the institutions. BPA was recognized by 92 percent of the respondents and correctly described by 40 percent. In contrast, the Power Council was recognized by only 37 percent of the respondents and correctly described by 12 percent (Northwest Attitudes and Social Research, Inc., 1982, pp. 10-12).

\subsection{IMPRESSIONS OF INSTITUTIONS}

Among the four energy institutions of the local utility, BPA, Northwest Power Planning Council, and the state energy office, the local utility had the highest favorability rating, followed by the state energy office. BPA and the Northwest Power Planning Council were the third and approximately on par with each other. The proportions of those indicating "very favorable" and "somewhat favorable" are as follows:

$\begin{array}{ll}\text { Local utility: } & 73 \% \\ \text { State energy office: } & 60 \% \\ \text { BPA: } & 48 \% \\ \text { Northwest Power Planning Council: } & 46 \%\end{array}$

\subsection{BELIEVABILITY OF INSTITUTIONS AS SOURCE OF ENERGY INFORMATION}

Respondents were asked to rank the believability of five energy institutions and six non-energy entities as energy information sources. These institutions are shown below:

\section{Energy Related}

o local utility

0 energy extention service

o BPA

- state energy office

o Northwest Power Planning Council
Not Energy Related

0 the media

o bank or credit union

o building contractor

o retail store

o local elected official

o realtor

Among these institutions and individuals, the local utility received the highest ranking; 87 percent of the respondents rated the local utility as "very believable" or "somewhat believable." Building contractors, the media, and banks or credit unions were the second group in terms of believability, with 70 
to 78 percent of the respondents regarding them as very or somewhat reliable. Retail stores, energy extension service, local elected officials, 8PA, and state energy offices were the third group, with the believability rating in the range of 58 to 63 percent. Northwest Power Planning Council and realtors were the last, with 48 percent.

The survey conducted for the Northwest Power Planning Council in February 1982 contained similar results, except that the media had a higher rating than the local utility. Table 4.1 provides a comparison of the two results. Note that the believability rating of the Northwest Power Planning Council rose from 33 percent to 48 percent, and that of the local utility rose from 71 percent to 87 percent. The rise in the Council's believability rating could partially be attributed to its accomplishments during 1982-83 including the publicity in the development of the Power Council's 1983 Power and Conservation Plan and the extensive and open public involvement process.

\subsection{SUMMARY}

To summarize the above discussion, the following can be noted:

- Among the energy institutions in the Pacific Northwest, the local utility was the most well known, the most favorably regarded, and the most trusted as a source of energy information.

o The believability rating of the media is relatively high; it is second only to the local utility.

- The energy extension service, BPA, and State Energy Office had about equal believability rating, but was lower than the local utility by more than 20 points, an average of 62 percent of the respondents regarded each of them as very or somewhat believable, compared to 87 percent for the local utility.

- Among the four energy institutions, the Power Council was the least known, least favorably regarded, and had the lowest believability rating. A major contributing factor to this situation is that the Power Council has been in existence only since 1981, while the other three institutions have been around much longer. In contrast, BPA was created by congress in 1937, and state energy offices were established by the states in the midto late-1970s. 
It follows from the abbove that attempts to promote and market energy conservation to the region's residents should definitely involve the local utility and the media.

TABLE 4.1. Believability of Institutions as Source of Energy Information

(\% very or somewhat believable)

Data Source and Applicable Date

RMH

Nov/83

Local utility

Bujlding contractor

The media

local TV station

local radio station

loca? newspaper

Bank or credit union

Retail store

Chamber of Commerce

Energy extension service

Local elected offical

BPA

State energy office

Northwest Power Planning Council

Realtor

Aluminum industry

Sierra Club

WPPSS
$87 \%$

73

73

$--$

$\rightarrow$

$--$

70

63

--

63

62

61

58

48

48

$--$

$-$

$-$
Power Council

$\mathrm{Feb} / 82$

\section{Data Sources}

RMH:

RMH Research, Inc. 1984. Table 50, p. 121.

Power Council: Northwest Attitudes and Social Research 1982. Table 22, p. 29. 


\subsection{TARGET PROSPECTS OF CONSERVATION INVESTMENTS}

The RMH study segmented homeowners in the Pacific Northwest into three groups in terms of their propensity to invest in conservation measures. This segmentation is based on past and potential future investment behaviors:

- First Tier Prospects were those who had already taken 8 or more specific conservation measures in the past and indicated a likelihood of investing in additional conservation measures requiring substantial capital. This group represented approximately 18 percent of the region's households, or 547,000 .

- Second Tier Prospects were those who had taken some (2 to 7) conservation investment measures and expressed a willingness to invest in full weatherization. This group accounted for about 22 percent of households in the region, or 695,700 households.

- Non-Prospects were homeowners who had undertaken less than one conservation measure and indicated that they would not adopt any additional energy conservation measures. There were $1,113,400$ households, or 36 percent of the households in the region.

Renters accounted for 24 percent of the area's households and were not included in the above classification. Compared to the non-prospect group, the first- and second-tier prospect groups were more likely to:

0 pay now, and expect to pay in the future, higher-than-average utility bills

o be better educated and to have higher income

o be younger

o be employed and in white-collar positions

o own a single-family home

o have a shorter length of stay at current address

o have a larger family size

o feel strongly that conserving energy is a social responsibility and, hence, more likely to be classified as altruists 
o have taken more passive and active energy conservation measures in the past

0 have used tax credits and financing (loans and credits) to pay for energy conservation investment

- consider for future installation of relatively expensive new technology such as solar panels, heat pumps, and sun space or passive solar

Table 5.1 presents the data supporting the above comparisons. 
TABLE 5.1. Comparison of Conservation Target Prospect Groups

Item

Current Average Monthly Energy Expenses (\$)

Average Monthly Bill in 5 Years (\$)

$\%$ with Some College or Degree

Male

Female

Mean Income (\$)

Age (years)

Male

Female

\% Employed

Male

Female

\% White Collar Occupation

cr

Male

Fend le

Mean Years at Address

\% Single-Family Home

Mean Number of People

\begin{tabular}{|c|c|c|c|}
\hline $\begin{array}{l}\text { First } \\
\text { Tier } \\
\end{array}$ & $\begin{array}{c}\text { Second } \\
\text { Tier }\end{array}$ & $\begin{array}{c}\text { Non- } \\
\text { Prospects }\end{array}$ & $\begin{array}{c}\text { Total } \\
\text { PNW }\end{array}$ \\
\hline $\begin{array}{r}73.4 \\
134.8\end{array}$ & $\begin{array}{r}69.9 \\
124.8\end{array}$ & $\begin{array}{r}65.8 \\
121.6\end{array}$ & $\begin{array}{l}-- \\
--\end{array}$ \\
\hline $\begin{array}{r}65 \\
56 \\
24,150\end{array}$ & $\begin{array}{r}58 \\
51 \\
23,420\end{array}$ & $\begin{array}{r}41 \\
36 \\
19,820\end{array}$ & $\begin{array}{r}50 \\
44 \\
20,440\end{array}$ \\
\hline $\begin{array}{l}44.6 \\
45.0\end{array}$ & $\begin{array}{l}43.4 \\
42.1\end{array}$ & $\begin{array}{l}49.9 \\
48.8\end{array}$ & $\begin{array}{l}43.4 \\
43.6\end{array}$ \\
\hline $\begin{array}{l}72 \\
53\end{array}$ & $\begin{array}{l}79 \\
50\end{array}$ & $\begin{array}{l}62 \\
38\end{array}$ & $\begin{array}{l}67 \\
46\end{array}$ \\
\hline $\begin{array}{c}39 \\
39 \\
6.5 \\
90 \\
3.3\end{array}$ & $\begin{array}{c}38 \\
38 \\
6.6 \\
90 \\
3.2\end{array}$ & $\begin{array}{c}29 \\
20 \\
7.2 \\
84 \\
2.7\end{array}$ & $\begin{array}{c}33 \\
32 \\
5.8 \\
76 \\
2.9\end{array}$ \\
\hline 46 & 40 & 39 & 36 \\
\hline 77 & 72 & 67 & 71 \\
\hline 23 & 25 & 30 & 26 \\
\hline $\begin{array}{l}37 \\
35\end{array}$ & $\begin{array}{l}35 \\
28\end{array}$ & $\begin{array}{l}48 \\
28\end{array}$ & $\begin{array}{l}42 \\
33\end{array}$ \\
\hline
\end{tabular}

$\%$ Strongly Agree with the Following Statement:

"Conserving energy is the best way to

protect the environment"

"It is our responsibility to conserve

electricity for future generations"

"The amount of energy I use is really my own affair and no one else's"

"I use electricity when it's really needed; there is no way I could cut down"

\% Regarding Energy Situation as Very Serious 
TABLE 5.1 (Con't)

\section{$\underline{\text { Item }}$}

\% Classified at Altruists

Average Percentage of all Items Installed in Home

* Used Tax Credit to Finance Conservation Investment

* Used Loan or Other Credit to Finance Conservation Investment

* Used Loan from Utility

* Very or Somewhat Likely to Install:

Solar panel for space heating

or

\begin{tabular}{cccc}
$\begin{array}{c}\text { First } \\
\text { Tier }\end{array}$ & $\begin{array}{c}\text { Second } \\
\text { Tier }\end{array}$ & $\begin{array}{c}\text { Non- } \\
\text { Prospects }\end{array}$ & $\begin{array}{c}\text { Total } \\
\text { PNW }\end{array}$ \\
\cline { 1 - 2 } 38 & 36 & 29 & -- \\
66 & 46 & 38 & -- \\
28 & 23 & 19 & 23 \\
20 & 11 & 11 & 13 \\
11 & 7 & 7 & 8 \\
29 & 14 & 2 & 12 \\
29 & 22 & 3 &
\end{tabular}




\subsection{RESPONSIVENESS OF CONSERVATION INVESTMENT TO PERCEIVED RETURN}

In a hypothetical question, approximately one-third of all respondents were asked to indicate the likelihood of investing $\$ 15$ per month for five years in an energy conservation measure if it would give them a net savings of $\$ 5$ per month over the same five-year period. Another one-third were asked about the likelihood of investing with zero net savings, while the final one-third were asked about the likelihood of investing with a negative net savings ${ }^{11}$ of $\$ 5$ per month. The respondents could answer "very likely," "somewhat likely," "not very likely," "not at all likely," or "not sure." The same patterns were repeated in a second question, with a $\$ 25$ per month investment for 10 years. However, no respondent was given the same savings figure at $\$ 25$ per month as he was given at $\$ 15$ per month.

The responses are summarized in the following tabulation:

LIKEL IHOOD OF INVESTING \$15 AND \$25 PER MONTH TO SAVE A SPECIFIC AMOUNT PER MONTH

\begin{tabular}{ccc} 
& (Very or Somewhat Likeiy) \\
\hline & $\begin{array}{c}\text { Wilingness } \\
\text { to invest }\end{array}$ & $\begin{array}{c}\text { Willingness } \\
\text { to invest }\end{array}$ \\
Monthly & $\begin{array}{l}\$ 25 \text { per month } \\
\text { for } 10 \text { yrs. }\end{array}$ & $\begin{array}{c}\$ 15 \text { per month } \\
\text { for } 5 \text { yrs. }\end{array}$ \\
\cline { 2 - 3 } Savings & $35 \%$ & $45 \%$ \\
$-\$ 5$ & $49 \%$ & $58 \%$ \\
0 & $60 \%$ & $64 \%$
\end{tabular}

The above results show that:

1 The term "negative net savings" simply means that the household apprared willing to spend $\$ 15$ per month on conservation investment in order to realize a savings of less than $\$ 15$ in energy costs for the postulated period. In purely monetary terms, the household spends more than the savings he would realize from the investment. 
- The proportion of respondents who said they were likely to make the specified conservation investment tends to increase with the perceived rate of return.

- The proportion of respondents who said they were likely to make the specified conservation investment tends to vary inversely with the amount of investment.

- A sizable portion of the respondents appears willing to make the conservation investment even if the apparent monetary rate of return was zero or negative.

The first two results are consistent with common expectations. The third result shown above is more problematical and, pending further investigation, the following discussion may be useful.

Economic theory suggests that, other things being equal, the rational man would not entertain an investment with negative rate of return. However, the resuit indicated that some individuals are willing to accept a negative or zero rate of return for the hypothetical conservation investment. What could be plausible explanations for such seemingly irrational behavior? One possible reason is that "returns" to conservation investments are not purely monetary. If "returns" other than monetary savings were included in the computation of the rate of return, then the true rate of return may not be negative at a 11 . Some examples of such other returns are psychis or non-market benefits such as increased comfort in the home, and the satisfaction derived from altruistic concerns, including doing their share of the social responsibility in conserving energy and protecting the environment. Another possibility is deferred monetary value; resale values of the nouse might be increased. Results on altruistic concerns and net increase in home value due to past conservation investments made have been discussed in Chapters 2 and 3 respectively. The increased comfort of the house from conservation investment is an item that was not explicitly convered in the RMH study, although it is generally accepted.

Another point also needs to be noted. The manner in which the hypothetical questions were posed leaves some aspects unspecified. As a result, the respondents may be making implicit assumptions which are different 
from one another, leading to different responses. For example, some respondents may assume that the benefits (energy cost savings) couid continue after the specified period while the monthly cost would not have to be incurred any more. Other respondents might assume both cost and benefits terminate at the saine time. 



\subsection{CONSERVATION INFRASTRUCTURE}

One unique feature of the RMH study is that data were also collected on the views and perceptions of the conservation infrastructure--those who were responsible for the design and implementation of conservation programs or those who were in a position to influence the funding of conservation programs--on a number of the same questions asked of the region's residents. In some of these questions, both the infrastructure members' perception of the public's attitudes and the infrastructure's own perceptions on the issues were obtained. In others, only their estimate of the resident's responses were asked. Thus, it is possible to contrast the estimates of the conservation infrastructure made on the residents responses with those of the residents and with their own views.

It should be noted that, in contrast to the general survey sample, the infrastructure sample is not random. A 1 ist of 122 individuals was compiled from utility conservation and general managers, BPA conservation staff and key decision makers, conservation staff members of state energy offices, members of the Northwest Power Planning Council and key staff. Each individual on the list was initially sent a letter from the Pacific Northwest Laboratory project manager explaining the nature of the project and the upcoming telephone interview that could be expected. Out of the 122 individuals, 98 telephone interviews were completed after two or three attempts.

The comparisons of the views and perceptions of energy conservation infrastructure with those of the region's residents can be made in four general areas: perceptions and attitudes on conservation and energy issues; energy conservation actions, investment, financing, and related items; perception of institutions; and responsiveness of conservation investment to perceived returns.

\subsection{PERCEPTIONS AND ATTITUDES ON CONSERVATION AND ENERGY ISSUES}

The infrastructure's perception of the understanding of the region's residents of the term "energy conservation" appeared to generally parallel those of the residents' own definition: 
Major Mention

Save electricity/use less electricity Conserve energy/save energy/use less

Use only as much as is needed/ don't waste energy, fuel

Turn off Tights when not in use/ turn down lights

Save money/cut utility bills

Insulate/use insulation

Turn down thermostat

Conservation as a way of 1 ife/

responsibility
Infrastructure

Perceived

$\underset{\%}{\operatorname{Res} i d e n t s}$

26

22

19

17

12

11

8

4
Resident Response

$\%$

17

21

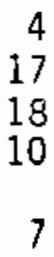

17

18

10

7

Members of the infrastructure tended to underestimate the intensity of concern by the region's residents about crime, inflation, environment, energy conservation, and energy use in the home. In contrast, the infrastructure's own concerns on these issues were closer to that of the residents'. Only with respect to cost of energy and unemployment were the infrastructure's perception of residents' responses consistent with the residents' own.

CONCERN ABOUT ISSUES

"\% Very Concerned"

\begin{tabular}{lccc} 
& & \multicolumn{2}{c}{ Infrastructure } \\
& $\begin{array}{c}\text { Rerceived } \\
\text { Residents }\end{array}$ & $\begin{array}{c}\text { Resident Responses } \\
\%\end{array}$ & $\begin{array}{c}\text { Own } \\
\text { Response } \\
\%\end{array}$ \\
Crime & 74 & 28 & 32 \\
Cost of energy & 70 & 68 & 64 \\
Inflation & 64 & 27 & 43 \\
Unemployment & 63 & 63 & 41 \\
Environment & 55 & 25 & 56 \\
Energy conservation & 48 & 17 & 44 \\
Energy use in the home & 48 & 23 &
\end{tabular}

With respect to perception of seriousness of the energy situation, the energy conservation infrastructure appeared to have entirely misjudged the residents' feelings, while the infrastructure's own feelings paralleled that of the residents'. 


\section{SERIOUSNESS OF ENERGY SITUATION}

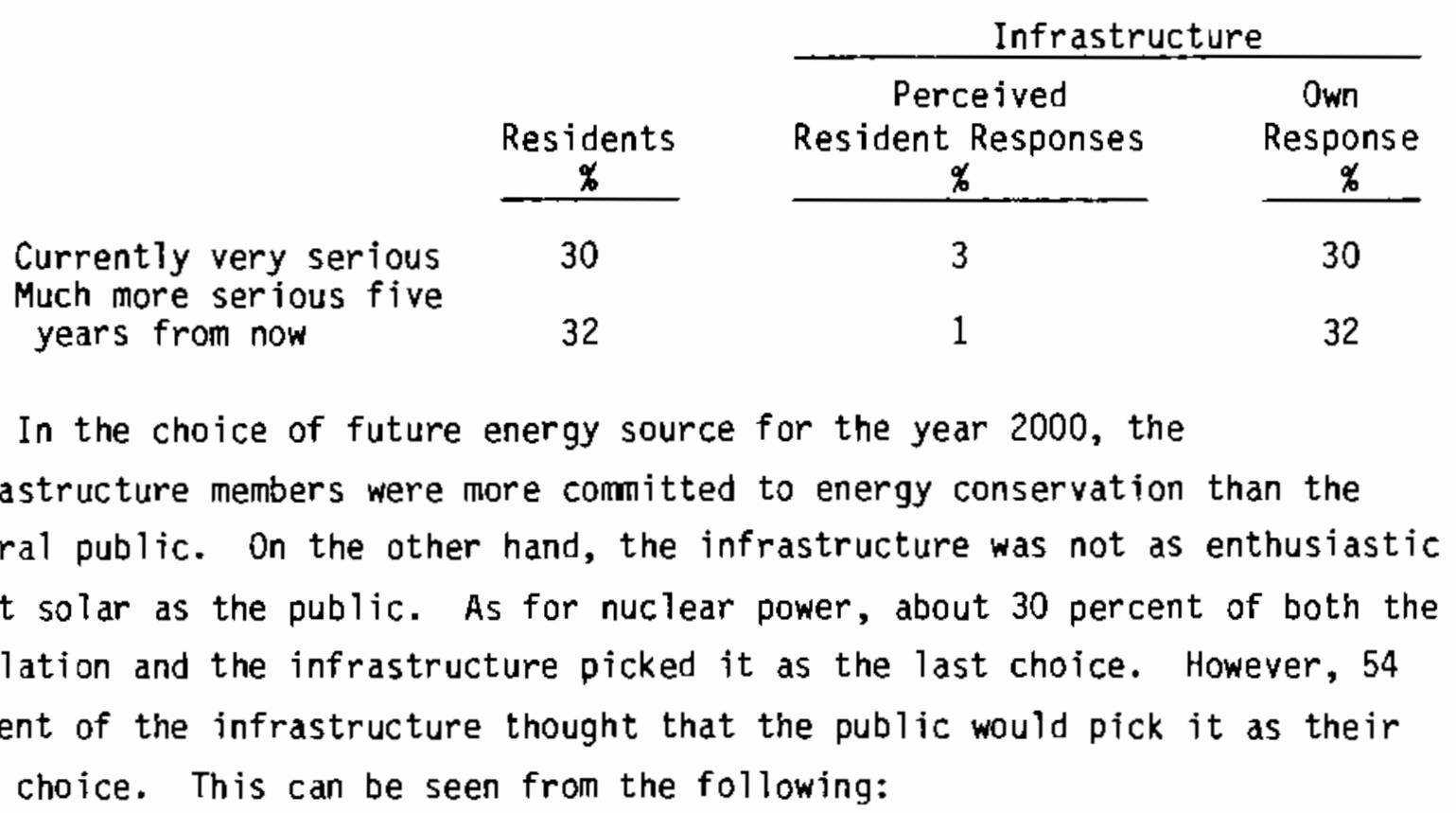

CHOICE FOR FUTURE ENERGY SOURCE FOR THE YEAR 2000

- Preferred 1st Choice $(\%)$

Resi- structure structure dents Estimates

Solar Hydroelectric Nuclear Energy cons. 12 Natural gas 9 Coal 0 il
33

23

12
20

38

4

31

2

6

\begin{tabular}{r} 
\\
Res \\
dent \\
\hline 6 \\
9 \\
30 \\
8 \\
9 \\
22 \\
8
\end{tabular}
Last Choice

(\%)

\begin{tabular}{llc} 
& Infra & Infra- \\
Resi- & structure & structure \\
dents & Estimates & Own \\
\hline
\end{tabular}

$\begin{array}{rr}12 & 6 \\ 27 & 9 \\ 19 & 30 \\ 30 & 8 \\ 1 & 9 \\ 9 & 22 \\ -- & 8\end{array}$

12

3

29

4

22

As for attitudes and feelings about energy conservation, the infrastructure membership were able to interpret the general public's negative feelings more often than interpreting their positive feelings. In other words, they seemed to understand the attitudes of the cynic and disheartened groups quite well, and appeared to underestimate the altrustic feeling of the general public. They did especially poorly with statements concerning social responsibility and cncern for the environment. Table 7.1 compares the results for each statement. 
TABLE 7.1. Percent of People Agreeing with the Statement

Infrastructure

Perceived

Resident

Personal

Residents

Response

Response

Most people who conserve electricity do so to save money

It's our responsibility to conserve electricity for future generations

I only use electricity when it's really needed; there's no way I could cut down 42

Conserving energy is the best way to protect the environment

Conserving energy is the best way to maintain my lifestyle

It's silly to conserve electricity because the electric utility just turns around and charges more for what you do use

The amount of energy I use is really my own affair and no one else's

My conservation efforts won't have much effect one way or the other on the availability of electricity

I would only make conservation improvements which would enhance the value of my home

I have already done everything I can to conserve energy

It is up to the local or federal government to initiate energy conservation; not individual homeowners 


\subsection{ENERGY CDNSERVATION ACTIONS, INVESTMENT, AND FINANCING}

Except for a few items, members of the infrastructure generally underestimated the proportions of the residents who regularly practiced no- or low-cost conservation actions as well as investment-type conservation actions. Underestimation occurred in no- or low-cost conservation actions such as using shade for heating and cooling, lowering the thermostat to 10 or more degrees when house was empty for four hours or more, selecting energy-efficient appliances, putting up plastic window coverings, and controlling lights with dimer switch or timer. For investment-type conservation actions, underestimation occurred with respect to insulation (roof, wall, and floor), weatherproofing, therma? pane and storm windows, storm doors, wood stoves, clock thermostat setback, heat pump, and sunspace (passive solar). Overestimation occurred in wrapping water heaters and free energy audits. The infrastructure's estimates were approximately correct for installing shower water-flow restictors and solar panels for space heating (Table 7.2).

The infrastructure's estimate of the average amount invested by the people over the 1981-1983 period was substantialiy less than the public's own estimate by a three-to-one margin--approximately $\$ 600$ vs. $\$ 1800$.

As for sources of funds for financing the investment in energy conservation and efficiency, the infrastructure members tended to underestimate the use of current income (including delaying other purchases and cutting back on purchases) and savings, and overestimated the use of loans from utilities, banks, payments by utilities, and tax credits (Table 7.3).

Compared to the expressed intention of the general public, the infrastructure perception of the public's intention to invest in conservation appeared to be on the optimistic side for weatherproofing, storm windows and thermal panes, insulation (floors, walls, and roof), and wood stoves, and somewhat more pessimistic on solar (passive or active) (Table 7.4).

The infrastructure appeared to have an accurate feeling about the source of the public's dissatisfaction of past conservation investment and actions, if any.

As to the preferred method of conserving energy, the infrastructure overestimated the willingness of the public to spend money on improvements--63 percent compared to 31 percent. In this respect, the infrastructure's estimate 
TABLE 7.2. Comparison of Infrastructure Perceptions With

Resident (CTaimed) Actual Conservation Actions

No/Low Cost Energy Conservation Measures

Infrastructure

Perception

Ratio:

Residents

(1)

of Residents

(2)

$\frac{(2) /(1)}{(3)}$

Underestimate

Use shades for heating and cooling

Lower thermostat 10 or more degrees

when home is empty

Select energy-efficient appliances

Put up plastic window coverings

Control lights with dimer or timer

$88 \%$

$77 \%$

.88

81

71

.88

71

.65

60

46

.67

45

40

.47

Overestimate

Wrap water heater

Receive free energy audit

62

27

35

39

1.11

82

1.32

62

2.30

About the Same

Install shower water flow restrictors

Investment-Type Conservation Measures

Underestimate

Insulate roof/attic

Weatherproofing

Storm window/thermal pane

71

67

Wood stove/furnace

Insulate walls

65

64

Storm or insulated doors

63

Insulate basement/craw? space

54

clock thermostat setback

29

Heat pump

11

Sunspace (passive solar)

11

$43 \%$

.56

.39

.36

.46

.42

.40

.37

.38

.64

.64

About the Same

Solar panels for space heating

1.00 
TABLE 7.3. Sources of Conservation Investment $F$ inancing

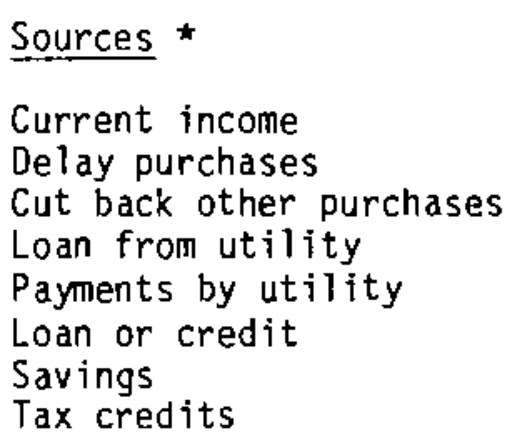

Respondent

Percentage ( $(x)$

Infrastructure Estimates (\%)

Current income

75

21

27

8

9

13

38

23

25

14

12

26

37

42

12

Tax credits

*Multiple sources included in the percentages

TABLE 7.4. Future Energy Conservation Improvements

(Very or Somewhat Likely)

$\underline{\text { t tem }}$

Respondents

Infrastructure

Weatherproofing

$10 \%$

Estimate

Storm windows/therma? pane widows

Heat pumps

11

Install automatic or clock thermostat setback

12

$23 \%$

Insulate basement, floor or craw? space

Sun space or other passive solar

11

$9 \quad 19$

Insulate outside walls

Insulate roof or attic

14

6

Solar panels for space heating

6

Storm or insulated doors

13

Wood stove or furnace

8

19

10

19
6

13

27

4

16

16 
of public willingness was more reflecting of their own preference (55 percent).

\begin{tabular}{|c|c|c|c|}
\hline & \multirow[b]{2}{*}{ Residents } & \multicolumn{2}{|c|}{ Infrastructure } \\
\hline & & $\begin{array}{l}\text { Perceived } \\
\text { Resident } \\
\text { Response } \\
\end{array}$ & $\begin{array}{l}\text { Personal } \\
\text { Response }\end{array}$ \\
\hline $\begin{array}{l}\text { Spend money on improvements } \\
\text { Change way of living } \\
\text { Both } \\
\text { Neither } \\
\text { Not sure }\end{array}$ & $\begin{array}{l}31 \% \\
50 \\
16 \\
2 \\
1\end{array}$ & $\begin{array}{l}63 \% \\
33 \\
4 \\
-- \\
--\end{array}$ & $\begin{array}{l}55 \% \\
36 \\
9 \\
-- \\
--\end{array}$ \\
\hline
\end{tabular}

The infrastructure's estimate of the decision makers on conservation investment approximately matched the respondents' expressed division of the decision making.

\subsection{PERCEPTION OF INSTITUTIONS}

As shown below, members of the conservation infrastructure underestimated the favorability given by residents to local utilities, state energy office, and BPA. The underestimation for BPA was particularly pronounced. Infrastructure's perception of residents' rating on the Northwest Power Planning Council paralleled the residents' own.

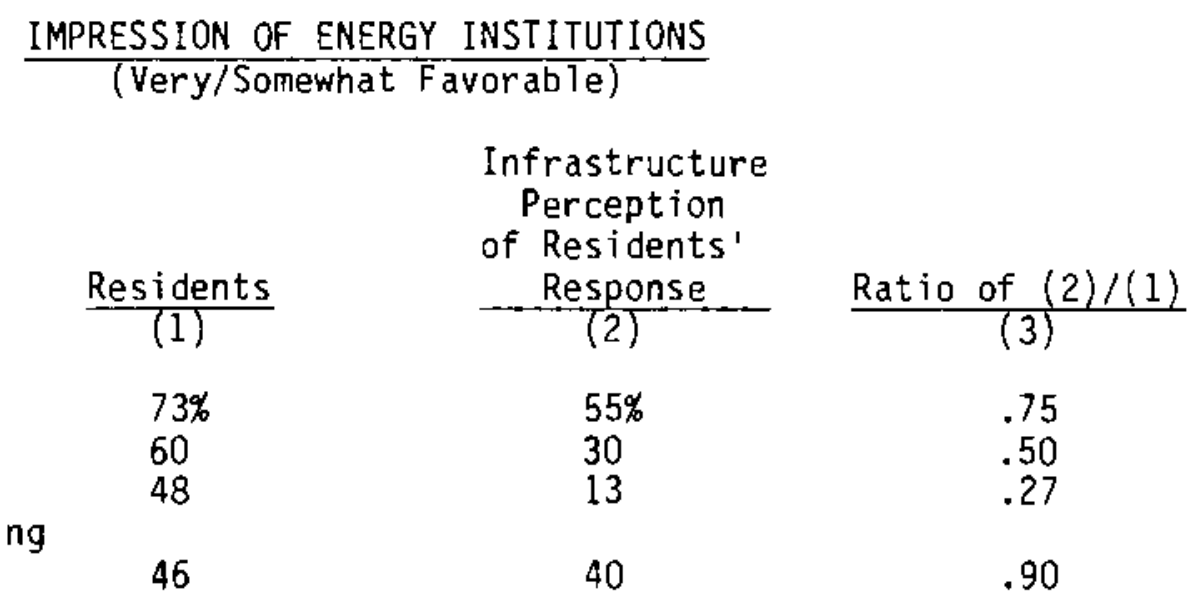

With respect to believability of energy conservation information provided, the infrastructure overestimated the residents' rating for most energy-reiated institutions, particularly for energy extension service and Northwest Power 
Planning Council. On the other hand, the infrastructure members' perception of residents' rating of belivability of energy information provided by non-energy related entities was much closer to the residents' own (Table 7.5 ).

\subsection{RESPONSIVENESS OF CONSERVATION INVESTMENT TO PERCEIVED RETURN}

As shown in Table 7.6, members of the infrastructure appeared to be in tune with the thinking of the general public in terms of the responses to a hypothetical question concerning the responsiveness of investment in conservation and energy efficiency to perceived rate of monetary return. According to the infrastructure's perception, the following can be observed:

o The proportion of consumers who would invest in energy conservation tends to increase with the perceived rate of return.

o The proportion of consumers who would invest in energy conservation tends to vary inversely with the amount of investment needed.

o Some consumers are willing to make investment in conservation even if the apparent rate of monetary return was zero or negative.

Compared to the consumers' own perception, the infrastructure's estimates of consumers' willingness to invest at negative or zero rate of monetary return are somewhat lower. At positive rate of monetary return, the infrastructure estimates of willingness to invest are either equal to or higher than consumers' expressed willingness.

\subsection{SUMMARY}

Generally, the infrastructure's perceptions of the general public's energy conservation attitudes in the four general topic areas are much more likely to disagree with the public's own perception than to agree. Where the two did not match, it was more likely for the infrastructure to underestimate the households' favorable attitudes toward conservation than to overestimate.

Areas of Correspondence. The infrastructure's perception of the atitudes of the general public approximately corresponded with the public's own revealed attitudes in the following areas:

- understanding of the term "energy conservation" 
TABLE 7.5. Believability of Energy Conservation Information Disseminated by Specific Sources

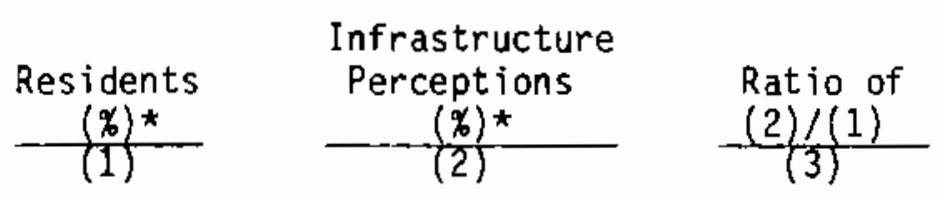

Energy-Related Institutions

$\begin{array}{llll}\text { Your local utility } & 87 & 93 & 1.07 \\ \text { Energy extension service } & 63 & 89 & 1.41 \\ \text { BPA } & 61 & 74 & 1.21 \\ \text { State energy office } & 58 & 74 & 1.28 \\ \text { Northwest Power Planning } & & & 1.48 \\ \quad \text { Council } & 48 & 71 & \end{array}$

Institutions Not Directly Related to Energy

* Percent of respondents indicating "very believable" or "somewhat believable."

Monthly

Savings

\begin{tabular}{ccc}
-5 & $\begin{array}{c}\text { Residents } \\
\text { Response }\end{array}$ & $\begin{array}{c}\text { Infrastructure } \\
\text { Estimate }\end{array}$ \\
\cline { 2 - 3 }-5 & $35 \%$ & $23 \%$ \\
0 & 49 & 41 \\
+5 & 60 & 61
\end{tabular}

$\begin{array}{llll}\text { Building contractor } & 73 & 75 & 1.03 \\ \text { The media } & 73 & 84 & 1.15 \\ \text { Bank or credit union } & 70 & 78 & 1.11 \\ \text { Retail store } & 63 & 65 & 1.05 \\ \text { Local elected official } & 62 & 43 & .90 \\ \text { Realtor } & 48 & \end{array}$

TABLE 7.6. Likelihood of Investing $\$ 15$ and $\$ 25$ Per Month To Save a Specific Amount Per Month

(Very or Somewhat Likely)

$$
\begin{gathered}
\text { Wi } 11 \text { ingness } \\
\text { to Invest }
\end{gathered}
$$

$\$ 25$ per Month

for 10 Years

61
Willingness

to Invest

$\$ 15$ per Month for 5 Years
.05

90 
o the intensity of the residents' concern about cost of energy and unemp loyment

- the respondent's negative feelings concerning energy use and energy conservation

- conservation actions taken by installing shower flow restrictors and installing solar panels for space heating

o general intentions to invest in heat pumps, automatic thermostat setback controls and storm or insulated doors in the next two to three years (19841986)

o sources or reasons of dissatisfaction on past conservation investments made

- division of conservation investment decision making between male and female head of households

- favorability of impression of Northwest Power Planning Council

- believability as sources of energy information of non-energy institutions such as building contractors, the media, banks or credit unions, local elected officials, retail stores, and realtors

- the general pattern of responsiveness of conservation investment to perceived rate of return.

Areas of Underestimation. The infrastructure's perception of public attitudes tended to underestimate the public's own revealed attitudes in the following areas:

o the intensity of the residents' concern about crime, inflation, environment, energy conservation, and energy use in the home

- the feeling of seriousness of the U.S. energy situation as of late 1983 and that it would get more serious five years hence

o solar energy as the preferred energy source in the future

- the residents' positive feelings concerning energy conservation, especially the feeling that energy conservation is a social responsibility and that energy conservation is the best way to protect the environment 
0 the degree to which the residents had regularly practiced no- or low-cost conservation actions such as using shades for heating and cooling, lowering thermostats 10 or more degrees when house was empty for four hours or more, selecting energy-efficient appliances, putting up plastic window coverings, and controlling lights with dimmer switches or timers

o the degree to which the residents had made investments in energy conservation, such as insulation (roof, wall, and floor), weatherproofing, thermal pane and storm windows, storm doors, wood stoves, clock thermostat setback, heat pump, and sunspace (passive solar)

0 the average amount of conservation investment made during 1981-1983

- the use of current income (including delaying other purchases and cutting back on other purchases) and savings to finance past conservation investments

0 intention to invest in both passive and active solar energy during 19841986

- favorability of impression of the local utility, state energy offices, and BPA

o the willingness of the general public to invest in energy conservation at negative or breakeven rate of monetary return.

Areas of Overestimation. In contrast, the infrastructure tended to overestimate the residents' responses in the following areas:

- the respondents' choice of energy conservation as a future source of energy

- the public opposition to nuclear power as a future source of energy

- the degree to which the respondents had taken action to wrap water heaters and to receive free energy audits

0 the use of loans from utilities and banks and tax credits to finance past conservation investment, or the investment was paid by the local utility

- future intention to invest in weatherproofing, thermal pane and storm windows, insulation (roof, walls, and floor), and wood stoves during 19841986 
- the public's willingness to spend money on conserving energy

- the believability of sources of energy information of energy institutions such as the local utility, BPA, state energy of fices, energy extension service, and the Northwest Power Planning Council--especially the last two entities. 


\subsection{IMPLICATIONS}

The results of a baseline residential energy conservation study for the Pacific Northwest conducted during 1983-84 have been presented and compared with available data from other surveys in Chapters 2 through 7 . In general, the results of the various studies have been found to be largely consistent with one another. Therefore, it is concluded that the baseline study results, with due consideration of the nature and limitations, can be used for conservation planning and marketing purposes. In concluding this report, several implications of the findings reported in the previous chapters are discussed. These include the overall conservation strategy in a period of power surplus, the role of local utilities and the media in fostering residential energy conservation, the role of surveys in conservation planning and program design, and further research.

1. Overall Energy Conservation Strategy. It is widely acknowledged that the Northwest is now in a period of firm power surplus, which may extend into the early 1990's. (S. Aos, 1985; BPA, 1983; Northwest Power Planning Counci1, 1982.) During such a period, the most appropriate energy conservation strategy is "capability building", instead of actual acquisition of conservation. In other words, the objective is to build the capability to acquire conservation resources quickly when the needs arise later, without actual purchases, except for cases with irreversability or high cost penalties in retrofitting or changes.

In terms of the target prospect groups explained in Chapter 5, the applicable marketing approach is as follows. First, instead of aggressively targeting the specific incentive or subsidy programs at the First Tier Prospects during the power surplus period, the emphas is should be on moving the Second Tier Prospects into the First Tier Prospects and to explore ways to reach the so-called Non-prospects and the rental housing market segment, the latter of which was not treated in the baseline survey. Second, public information through the local utilities and the news media could be used to maintain the conservation interests of the First Tier Prospect so that they will either implement conservation measure on their own over time or maintain their "first tier" status. 
2. Role of Local Utilities and Media. As explained in Chapter 4, the local utilities and the media have, respectively, the highest and second highest believability ratings with respect to energy conservation information. Moreover, the local utility is much more widely known and more favorably regarded than state energy offices, BPA, and the Power Council. It follows that attempts to promote energy conservation in the residential sector should definitely involve the local utility and the media.

3. Role of Surveys. Results in Chapter 7 suggests that there is a gap between the general public's own views and those views as perceived by the conservation infrastructure. In conservation planning and program design, the infrastructure's perceptions are often incorporated into the planning assumptions. To avoid making biased assumptions and to select the appropriate assumptions for conservation planning and program design, it is useful to conduct relevant surveys and studies to assess household attitudes, interests, and opinions.

4. Further Research. It will be necessary to conduct periodic surveys and assessments to track the changes in attitudes, interests, and opinions on energy conservation of households in the region. In addition to such recurring generai survey, other surveys and studies with a more concentrated focus should also be conducted. Moreover, other surveys conducted by others should cont inue to be monitored and reviewed for comparison with the baseline and tracking studies.

In this aspect, PNL has also conducted surveys and studies for BPA on the marketing environment of heat pump and solar water heaters, and energyefficient new homes. (RMH Research, Inc. 1984c; Hendrickson, 1984; Bardsley \& Haslacher, Inc. 1984) Studies on multifamily housing and mobile homes are in progress. (Hendrickson, et. al. 1985) Planning to repeat the baseline survey with refined survey instrument (Phase II) has also been started with the target survey date in late, 1985.

5. Qualifications. It should be noted that other studies used for comparison in this report are not exhaustive. Additional studies have come to our attention after the primary work on this report was completed. It is planned that, in the Phase II work of the project just noted, these additional study results will be included in a tracking and comparison report. 
It should also be noted that the approach in comparing results from different studies is primarily qualitative. Given the divergence in sample selection, geographical coverage, definition of terms, and the manners in which the individual questions were phrased, strict applications of statistical tests of significance is not appropriate, if not impossible. 
$$
2
$$ 


\section{REFERENCES}

Aos, S. 1985. "How Long Will the Surplus of Electricity Last?" In WSEO: Washington State Energy Office Newsletter, 8(1):1-2, January.

Bardsley \& Haslacher, Inc. 1984. Northwest New Home 8uyers Discuss the Home Purchase Decision. Final Report. Prepared for Pacific Northwest Laboratory, August.

Bonneville Power Administration (BPA). 1983. Selling Power - Issue Backgrounder: Surplus Power. SLP-3-3, November.

Elrick and Lavidge, Inc. 1980. The Pacific Northwest Residential Energy Survey, Vol. 1. Executive Surmary. Prepared for Bonnevilile Power Administration and the Pacific Northwest Utilities Conference Committee, July 1980 .

Hendrickson, P.L. 1984. Review of Survey Data on the Importance of Energy Efficiency to New Home Buyers. PNL-5297. Pacific Northwest Laboratory, Richland, Washington, October.

Hendrickson, P.L., A.D. Lee and B.L. Mohler. 1985. Preliminary Report on Marketing Energy Conservation Options to Northwest Manufactured Home Buyers. Working Paper, Pacific Northwest Laboratory, Richland, washington, Aprî.

Northwest Attitudes and Social Research, Inc. 1982. Baseline Energy Survey. Conducted for the Northwest Power Planning Council, February 1982.

Northwest Ppower Planning Council. 1982. "Weighing the New Surplus." In Northwest Energy News, $1(5): 1,7-9,17-20$. August.

Oregon Department of Energy 1983. Oregon Residential Energy Study: An Update, April 1983.

RMH Research, Inc. 1984a. The Marketing Environment for Energy Conservation in the Pacific Northwest. Prepared for the Pacific Northwest Laboratory, May To84.

RMH Research, Inc. 1984b. The Marketing Environment for Energy Conservation in the Pacific Northwest: Executive Surmary. Prepared for the Pacific Northwest Laboratory, May 1984.

RMH Research, Inc. 1984c. The Marketing Environment for Solar and Heat Pump Water Heaters. Prepared for the Pacific Northwest Laboratory, May 1984.

Western Rural Development Center, 1982. Energy Directions for the United States: A Western Perspective. Publication No. 13, August 1982. 
APPENDIX A

DETALLED SUPPORTING TABLES FOR FIGURE 3.1 
APPENDIX A DETAILED SUPPORTING TABLES FOR FIGURE 3.1

This appendix contains detailed information on the proportions of homes in the Pacific Northwest with specific energy conservation measures such as insulation in outside walls, weatherproofing, thermal pane or storm windows, storm or insulated doors, wood stoves, and clock thermostat setback controls. Note that, in order to make possible the comparisons among different data sources, the RMH survey results have been interpreted in the extreme as saturation ratios. To provide the proper background of the data sources, the questions asked in the various surveys are provided. The discussion in Section 3.1 explains some of the major caveats in this interpretation. 
TABLE A.1. Proportions of Homes with Insulation in Outside Walls in the Pacific Northwest, by State

(x)

\begin{tabular}{|c|c|c|c|c|c|c|c|}
\hline & Year & Data Source & $\begin{array}{l}\text { Pacific } \\
\text { Northwest }\end{array}$ & Idaho & Oregon & Washington & Montana (a) \\
\hline $1978 \&$ & $\begin{array}{l}\text { Earlier(b) } \\
1979 \\
1979 / 80 \\
1981 \\
1982 \\
1983(\mathrm{c})\end{array}$ & $\begin{array}{l}\text { WROC } \\
\text { ODOE } \\
\text { PNWRES79/80 } \\
\text { WRDC } \\
\text { ODOE } \\
\text { RMH }\end{array}$ & $\begin{array}{l}-- \\
-- \\
62 \\
-- \\
-- \\
64\end{array}$ & $\begin{array}{l}51 \\
7- \\
76 \\
68 \\
-- \\
69\end{array}$ & $\begin{array}{l}49 \\
47 \\
57 \\
60 \\
59 \\
64\end{array}$ & $\begin{array}{l}46 \\
60 \\
57 \\
-- \\
66\end{array}$ & $\begin{array}{l}52 \\
-- \\
76 \\
67 \\
-- \\
71\end{array}$ \\
\hline
\end{tabular}

Sources: WRDC: Western Rural Development Center 1982. Table 68, p. 120.

PNWRES 79/80: Elrick \& Lavidge, Inc. 1980. Vol. 1. Exhibit 10, p. 29.

ONOE: Oregon Department of Energy 1983, p. 16.

RMH: RMH Research, Inc. 1984. Table 32, p. 8i. See also notes (c) and (d) below.

\section{Questions asked}

WRDC:

"Listed below are certain energy saving features that might be added to your home (by you or if you rent, your landlord). For each item, please circle the one best answer:

o Extsted when I moved in

o Added since I moved in

- Plan to add within two years

o Doesn't exist and no plans to add in two years

o I don't know

o Doesn't apply to my home." 
TABLE A.l. (cont.)

ODOE: $\quad$ "Is your residence equipped with any of the following? (Please circle the numbers of all that apply.)"

PNRES79/80: "First, how about your exterior walls--do you have any insulation in any of your exterior walls?",

RMH:(d) "Have you paid for material and/or labor to have (item from list) installed in your home?"

Footnotes

(a) For Montana, the PNRES79/80 and RMH figures cover only Western Montana while the WRDC figures cover all Montana.

(b) As shown above in the question asked for the WRDC study, the first category is "Existed when I moved in." Since the survey was conducted in early 1981 and the average stay is more than two years at a time, the term "1978 and Earlier" is used for convenience and should not be viewed as a precise indication of time.

(c) The RMH figures used four geographical regions: Northwest (NW), Southwest (SW), Northeast (NE) and Southeast $(S E)$. Washington State figure was derived from simple average of NW and NE. Oregon value was derived from simple average of SW and SE. Idaho value was calculated from simple average of NE and SE. Montana value is assigned from NE.

(d) In the text and accompanying tables in the RMH report (RMH Research, Inc. 1984), the question was mistakenly printed as "Is your house currently equipped with the following energy conservation improvements?" The question in the survey instruments as shown in Appendix B in the RMH report is the correct question. 
TABLE A.2. Proportions of Momes with Keatherproofing (Weatherstripping and Caulking) in the Pacific Northwest, by State

$(\%)$

\begin{tabular}{|c|c|c|c|c|c|c|c|}
\hline & Year & Data Source & $\begin{array}{c}\text { Pacific } \\
\text { Northwest } \\
\end{array}$ & I daho & Oregon & Washington & Montana \\
\hline \multirow{6}{*}{$1978 \mathrm{~g}$} & Earlier (b) & WRDC & $\ldots$ & 37 & 35 & 34 & 37 \\
\hline & 1979 & ODDE & -- & $=-$ & 66 & -- & - \\
\hline & $1979 / 80^{(c)}$ & PNWRES79/80 & 66 & 79 & 69 & 61 & 74 \\
\hline & 1981 & WRDC & $=$ & 75 & 67 & 66 & 78 \\
\hline & 1982 & ODOE & $\cdots$ & -- & 72 & $=$ & -- \\
\hline & 1983 (a) & & 71 & 72 & 70 & 71 & 73 \\
\hline
\end{tabular}

Sources: WRDC: Western Rura! Development Center 1982, Table 66, p. 8.

PNwRES 79/80: Elrick \& Lavidge, Inc. 1980. Exhibit 13, p. 36.

ODOE: Oregon Department of Energy 1983, p. 16.

RMH: RMH Research, Inc. 1984. Table 32, p. 81. See also notes (d) and (e) below.

\section{Questions asked}

HROC:

"Listed below are certain energy saving features that might be added to your home (by you or if you rent, your landlord). For each item, please circle the one best answer:

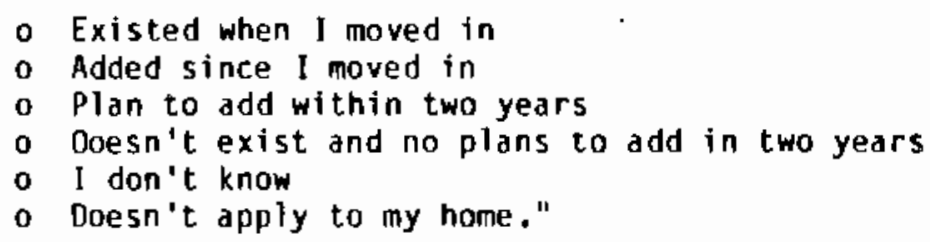


TABLE A.2. (cont.)

ONOE: "Is your residence equipped with any of the following? (Please circle the numbers of all that apply.)"

PNWRES79/80: "For each item on the list, please tell me whether you don't have it now, or have it on only some - or have it on all outside windows and/or doors?" RMH: (e) "Have you paid for material and/or labor to have (item from list) installed in your

\section{Footnotes}

(a) For Montana, the PNRES79/80 and RMH figures cover only Western Montana while the WRDC figures cover all Montana.

(b) As shown above in the question asked for the WROC study, the first category is "Existed when I moved in." Since the survey was conducted in early 1981 and the average stay is more than two years at a time, the term "1978 and Eariter" is used for convenience and should not be viewed as a precise indication of time.

(c) The PNRES79/80 and ODOE data have separate entries for weatherstripping and caulking. In all cases, the proportions for weatherstripping are higher than those for caulking. Hence, only those of weatherstripping are shown here.

(d) The RMH figures used four geographical regions: Northwest (NH), Southwest (SH), Northeast (NE) and Southeast (SE). Washington State figure was derived from simple average of NW and NE. Oregon value was derived from simple average of SW and SE. Idaho value was calculated from simple average of NE and SE. Montana value is assigned from NE.

(e) In the text and accompanying tables in the RMH report (RMH Research, Inc. 1984), the question was mistakenly printed as " 15 your house currently equtpped with the following energy conservation improvements?" The question in the survey instruments as shown in Appendix B in the RMH report is the correct question. 
IABLE A.3. Proportions of Homes with Thermal Pane or Storm Windows in the Pacific Northwest, by State

(2)

\begin{tabular}{|c|c|c|c|c|c|c|c|}
\hline & Year & Data Source & $\begin{array}{c}\text { Pacific } \\
\text { Northwest } \\
\end{array}$ & Idaho & Oregon & Washington & Montana (a) \\
\hline $1978 \&$ & $\begin{array}{l}\text { Earlier } \\
1979 \\
1979 / 80 \\
1981 \\
1982 \\
1983\end{array}$ & $\begin{array}{l}\text { WRnC (b) } \\
\text { ODOE } \\
\text { PNWRES 79/80 } \\
\text { WRDC } \\
\text { ODOE } \\
\text { RMH (c) }\end{array}$ & $\begin{array}{l}-- \\
-\overline{45} \\
-- \\
-- \\
67\end{array}$ & $\begin{array}{l}50 \\
-- \\
70 \\
78 \\
-- \\
75\end{array}$ & $\begin{array}{l}25 \\
53 \\
41 \\
56 \\
68 \\
67\end{array}$ & $\begin{array}{l}28 \\
-- \\
33 \\
49 \\
-- \\
70\end{array}$ & $\begin{array}{l}68 \\
-- \\
89 \\
87 \\
-- \\
77\end{array}$ \\
\hline
\end{tabular}

Sources: HRDC: Western Rural Development Center 1982. Table 65, p. 117.

or PNHRES 79/80: Elrick \& Lavidge, Inc. 1980. Exhibit 13, p. 36.

ODOE: Oregon Department of Energy 1983, p. 16.

RMH: RMH Research, Inc. 1984. Table 32, p. 81. See also notes (c) and (d) below.

\section{Questions asked}

HRDC:

"Listed below are certain energy saving features that might be added to your home (by you or if you rent, your landlord). For each item, please circle the one best answer:

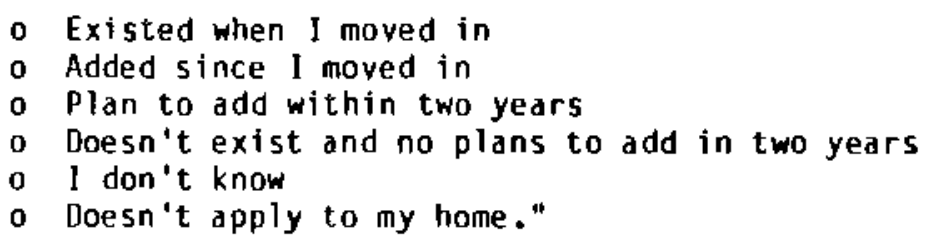


TABLE A.3. (cont.)

ODOE: "About what percent of the total window area of your'house is insulated? (Count double- and triple-glazed windows, storm windows, and plastic coverings.)"

PNWRES79/80: "How many of (large, medium, sma11) windows have storm windows or insulating glass?"

RMH: (d) "Have you paid for material and/or labor to have (item from list) installed in your home?"

\section{Footnotes}

(a) For Montana, the PNRES79/80 and RMH figures cover only Western Montana while the WRDC figures cover all Montana.

(b) As shown above in the question asked for the WROC study, the first category is "Existed when I moved in." Since the survey was conducted in early 1981 and the average stay is more than two years at a time, the term "1978 and Earlier" is used for convenience and should not be viewed as a precise indication of time.

(c) The RMH figures used four geographical regions: Northwest (NW), Southwest (SW), Northeast (NE) and Southeast (SE). Washington State figure was derived from simple average of NH and ME. Oregon value was derived from simple average of SW and SE. Idaho value was calculated from simple average of NE and SE. Montana value is assigned from NE.

(d) In the text and accompanying tables in the RMH report (RMH Research, Inc. 1984), the question was mistakenly printed as "Is your house currently equipped with the following energy conservation improvements?" The question in the survey instruments as shown in Appendix B in the RMH report is the correct question. 
TARLE A.4. Proportions of Homes with Storm or Insulated Doors in the Pacific Northwest, by State

(x)

\begin{tabular}{|c|c|c|c|c|c|c|}
\hline Year & Data Source & $\begin{array}{c}\text { Pacific } \\
\text { Northwest } \\
\end{array}$ & Idaho & Oregon & Washington & Montana (a) \\
\hline Earlier & WRDC ${ }^{(b)}$ & -- & 29 & 15 & 20 & 52 \\
\hline 1979 & ODOE & -- & $\cdots$ & -- & -. & -- \\
\hline $1979 / 80$ & PNWRES $79 / 80$ & 48 & 67 & 41 & 42 & 81 \\
\hline 1981 & WRDC & - & 52 & 37 & 40 & 72 \\
\hline 1982 & $000 E_{1}$ & -- & -- & 47 & -- & -- \\
\hline 1983 & $\mathrm{RMH}^{(\mathrm{C})}$ & 63 & 73 & 64 & 65 & 76 \\
\hline
\end{tabular}

Sources: WRDC: Western Rural Development Center 1982. Table 70, p. 122.

PNWRES 79/80: Elrick \& Lavidge, Inc. 1980. Exhibit 13, p. 36.

ODOE: Oregon Departinent of Energy 1983, p. 16.

RMH: RMH Research, Inc. 1984. Table 32, p. 81. See also notes (c) and (d) below.

\section{Questions asked}

WROC:

"Listed below are certain energy saving features that might be added to your home (by you or if you rent, your landlord). For each item, please circle the one best answer:
0 Existed when I moved in
- Added since I moved in
- Plan to add within two years
o Doesn't exist and no plans to add in two years
- I don't know
o Doesn't apply to my home." 
TABLE A.4. (cont.)

ODOE: $\quad$ "Is your residence equipped with any of the following? (Please circle the numbers of all that apply.)"

PNWRES79/80: "How many of your doors to the outside have storm doors?"

RMH: (d) "Have you paid for material and/or labor to have (item from list) installed in your home?"

\section{Footnotes}

(a) For Montana, the PNRES79/80 and RMH figures cover only Western Montand while the WRDC figures cover all Montana.

(b) As shown above in the question asked for the WRDC study, the first category is "Existed when I moved in." Since the survey was conducted in early 1981 and the average stay is more than two years at a time, the term "1978 and Earlier" is used for convenience and should not be viewed as a precise indication of time.

(c) The RMH figures used four geographical regions: Northwest (NH), Southwest (SW), Northeast (NE) and Southeast (SE). Washington State figure was derived from simple average of NW and NE. Oregon value was derived from simple average of SW and SE. Idaho value was calculated from simple average of $\mathrm{NE}$ and $\mathrm{SE}$. Montana value is assigned from NE.

(d) In the text and accompanying tables in the RMH report (RMH Research, Inc. 1984), the question was mistakenly printed as "Is your house currently equipped with the following energy conservation improvements?" The question in the survey instruments as shown in Appendix $B$ in the RMH report is the correct question. 
TABLE A.5. Proportions of Homes with Wood Stoves

in the Pacific Northwest, by State

(x)

\begin{tabular}{|c|c|c|c|c|c|c|c|}
\hline & Year & Data Source & $\begin{array}{l}\text { Pacific } \\
\text { Northwest }\end{array}$ & Idaho & Oregon & Washington & Montana (a) \\
\hline \multirow[t]{6}{*}{19788} & Earlier (b) & WROC & -- & 13 & 11 & 70 & 6 \\
\hline & 1979 & ODOE & - & - & 15 & -- & -- \\
\hline & $1979 / 80$ & PNWRE579/80 & 20 & 26 & 25 & 14 & 22 \\
\hline & 1981 & WRDC & -- & 42 & 40 & 26 & 29 \\
\hline & 1982 & ODOE & -- & - & 31 & -- & - \\
\hline & $1983(c)$ & RMH & 65 & 70 & 69 & 64 & 67 \\
\hline
\end{tabular}

Sources: WRDC: Western Rural Development Center 1982. Table 73, p. 125.

PNWRES 79/80: Elrick \& Lavidge, Inc. 1980. Exhibit 21, p. 49.

DDOE: Oregon Department of Energy 1983, p. 9.

RMH: RMH Research, Inc. 1984. Table 32, p. 81. See also notes (c) and (d) below.

Questions asked

WRDC:

"Listed below are certain energy saving features that might be added to your home (by you or if you rent, your landlord). For each item, please circle the one best answer:

o Existed when I moved in

o Added since I moved in

a Plan to add within two years

- Doesn't exist and no plans to add in two years

- I don't know

Doesn't apply to my home." 
TABLE A.5. (cont.)

ODOE: $\quad$ "What is the main type of equipment used to heat your residence? What type of additional heating equipment, if any, do you use to heat your residence - wood stove or wood furnace?"

PNWRES79/80: "Have any of these types of equipment been used during the past 12 months in your home in addition to your main equipment - heating stoves burning wood, coal or coke?"

RMH: (d) "Have you paid for material and/or labor to have (item from list) installed in your hame?"

\section{Footnotes}

(a) For Montana, the PNRES79/80 and RMH figures cover only Western Montana while the WRDC figures cover all Montana.

(b) As shown above in the question asked for the WRDC study, the first category is "Existed when 1 moved in." Since the survey was conducted in early 1981 and the average stay is more than two years at a time, the term "1978 and Earlier" is used for convenience and should not be viewed as a precise indication of time.

(c) The RMH figures used four geographical regions: Northwest (NW), Southwest (SW), Northeast (NE) and Southeast (SE). Hashington State figure was derived from simple average of $\mathrm{NH}$ and NE. Oregon value was derived from simple average of SW and SE. Idaho value was calculated from simple average of NE and SE. Montana value is assigned from NE.

(d) In the text and accompanying tables in the RMH report (RMH Research, Inc. 1984), the question was mistakenly printed as "Is your house currently equipped with the following energy conservation improvements?" The question in the survey instruments as shown in Appendix B in the RMH report is the correct question. 
IABLE A.6. Proportions of Homes with Clock Thermostat Setback in the Pacific Northwest, by State

(\%)

\begin{tabular}{|c|c|c|c|c|c|c|c|}
\hline & Year & Datd Source & $\begin{array}{c}\text { Pacific } \\
\text { Northwest }\end{array}$ & Idaho & Oregon & Washington & Montana (a) \\
\hline $1978 \&$ & Earlier(b) & WRDC & -- & 6 & 6 & 10 & 8 \\
\hline & 1979 & ODOE & $=$ & $\infty$ & 9 & -- & -- \\
\hline & $1979 / 80$ & PNWRES $79 / 80$ & -- & - & -- & -- & - \\
\hline & 1981 & WRDC & $\ldots$ & 13 & 13 & 17 & 15 \\
\hline & 1982 & ODOE & -- & - & 12 & $=$ &.- \\
\hline & $1983^{(c)}$ & RMH & 29 & 32 & 27 & 31 & 34 \\
\hline
\end{tabular}

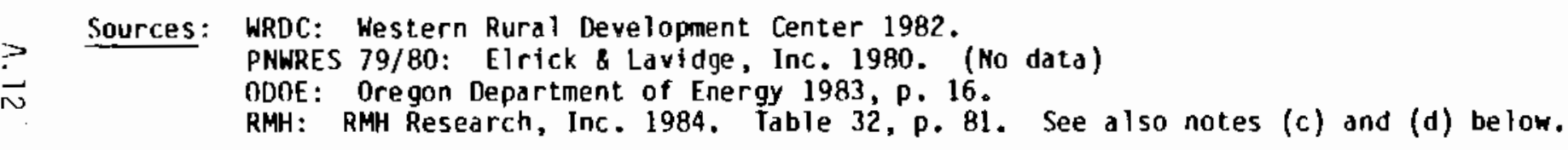

\section{Questions asked}

WRDC:

"Listed beiow are certain energy saving features that might be added to your home (by you or if you rent, your landlord). For each item, please circle the one best answer:

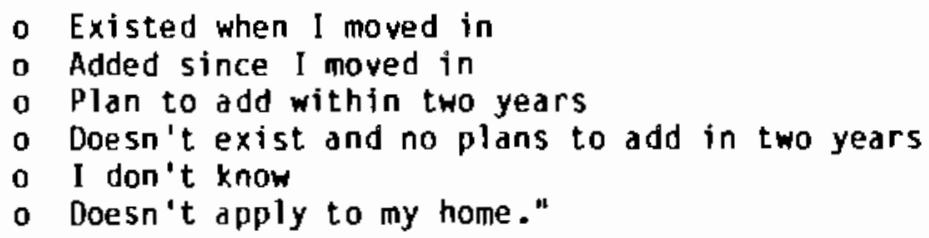


TABLE A.6. (cont.)

ODOE: $\quad$ "Is your residence equipped with any of the following? (Please circle the numbers of all that apply.)"

PNWRES79/80: "First, how about your exterior walls--do you have any insulation in any of your exterior walls?"

RMH: (d) "Have you paid for material and/or labor to have (item from list) installed in your home?"

\section{Footnates}

(a) For Montana, the PNRE579/80 and RMH figures cover only Western Montana while the WRDC figures cover all Montana.

(b) As shown above in the question asked for the WROC study, the first category is "Existed when I moved in." Since the survey was conducted in early 1981 and the average stay is more than two years at a time, the term "1978 and Earlier" is used for convenience and should not be viewed as a precise indication of time.

(c) The RMH figures used four geographical regions: Northwest (NW), Southwest (SW), Mortheast (NE) and Southeast (SE). Washington State figure was derived from simple average of $N H_{\text {and }} \mathrm{ME}$. Oregon value was derived from simple average of $\mathrm{SW}$ and $\mathrm{SE}$. Jdaho value was calculated from simple average of $\mathrm{NE}$ and $\mathrm{SE}$. Montana value is assigned from ME.

(d) In the text and accompanying tables in the RMH report (RMH Research, Inc. 1984), the question was mistakenly printed as "Is your house currently equipped with the following energy conservation improvements?" The question in the survey instruments as shown in Appendix $B$ in the RMH report is the correct question. 
APPENDIX B

INFORMATION ON RENTERS AND RENTAL UNITS 
APPENDIX 8 INFORMATION ON RENTERS AND RENTAL UNITS

The RMH study adopted a conservation marketing approach. Since renters were presumed to have little incentive to invest in improvements in energy efficiency in the rental units which they did not own, they were not analyzed in any detail. Those renters who did not pay the electricy bills themselves were screened out from the sample entirely. Only those who did pay electricity bills directly were included in the sample. The RMH study limited its treatment of renters and rental units to the demographic profile of those renters included in the sample, preference on methods to conserve energy, lowcost energy conservation action, energy conservation improvements made by landlords, and future improvements perceived to be needed by the tenants. The relevant inforination from the RMH survey are sumarized for reference purposes.

\section{B. 1 DEMOGRAPHIC PROFILE OF RENTERS}

About one in four households (24 percent) in the region were renters. Compared to homeowners who have been segmented into prospect and non-prospect. groups, renters as a group were generally younger and had lower incomes and a shorter stay in the current residence, had the lowest proportion living in single-family houses, the smallest number of bathrooms in the residence, and the smallest household size. Generaliy, renters were more comparable to the non-prospect group than to the prospect. There were two exceptions, though: in female employment ratio and education level. Each of these items is briefly noted below.

Average Age: 35 for renters, compared to 44 for prospects and 50 for nonprospects.

Mean Income: About $\$ 15,100$ for renters, compared to $\$ 23,000-\$ 24,000$ for prospects and $\$ 19,800$ for non-prospects.

Average Length of Stay in Current Residence: 2.3 years for renters, compared to 6.5 years for prospects and 7.2 years for non-prospects.

Proportion of Single-family Homes: 42 percent for renters, compared to 90 percent for prospects and 84 percent for non-prospects.

Number of Bathrooms: 1.2 for renters, commpared to 1.6 for non-prospects and 1.7 to 1.8 for prospects. 
Number of Persons in Residence: 2.6 for renters, compared to 2.7 for nonprospects and 3.2 for prospects.

Proportion Employed--Male: 59 percent for renters, compared to 76 percent for prospects and 62 percent for non-prospects.

Proportion Employed--Female: 46 percent for renters, compared to 52 percent for prospects and 38 percent for non-prospects.

Proportion With Some College or More--Male: 59 percent for renters, compared to 62 percent for prospects and 41 percent for non-prospects.

Proportion With Some College or More--Female: 57 percent for renters, compared with 54 percent for prospects and 36 percent for non-prospects.

\section{B.2 PREFERRED METHOD FOR CONSERVING ENERGY}

The general pattern of preferred method of conserving energy by renters is similar to that of homeowners. This can be seen from the following results.

Preferred Method

Spending money on improvement Changing way of life

Both

Neither

Not sure
Homeowners

$29 \%$

$52 \%$

$16 \%$

$2 \%$

$1 \%$
Renters

$37 \%$

$46 \%$

$15 \%$

$1 \%$

$1 \%$

\section{B.3 LOW-COST ENERGY CONSERVATION ACTIONS}

Except for the really low-cost items such as "use shades for heating or cooling" and "lower thermostat setting when room is to be unoccupied for a long period of time," renters were less likely than homeowners to have taken most of the low-cost energy conservation actions included in the survey. The following comparison shows the specific proportions of respondents indicating that they have taken the action identified. 


\begin{tabular}{lcc} 
Action Taken & Renters \\
\cline { 1 - 2 } & & \\
Use shades for heating or cooling & $88 \%$ & $87 \%$ \\
Lcwer themostat 10 or more degrees & & \\
when house is empty for 4 or & & \\
more hours & $81 \%$ & $82 \%$ \\
Select energy-efficient appliances & $74 \%$ & $60 \%$ \\
Wrap water heaters & $64 \%$ & $54 \%$ \\
Put up plastic window covering & $67 \%$ & $37 \%$ \\
Control lights with dimmer or timer & $49 \%$ & $35 \%$ \\
Install water flow restrictor & $38 \%$ & $25 \%$ \\
Receive d free energy audit & $30 \%$ & $18 \%$
\end{tabular}

\section{B.4 ENERGY CONSERVATION ACTIONS 8Y LANDLORDS}

When asked what energy conservation actions were taken by their landiords on the units they were occupying, over half of the renters (57 percent) responded by indicating that there were none taken or that they did not know. Otherwise, 36 percent mentioned insulation and weatherproofing, and 7 percent noted new heating sources such as stoves and new furnaces. Five percent of the renters indicated other energy-saving measures, such as lower thermostat and water temperature settings.

\section{B.5 NEEDED IMPROVEMENTS}

Over half ( 52 percent) of renters indicated that more insulation or weatherproofing was needed. About one in ten (13 percent) said that improvement in heating systems was necessary and iess than one in twenty (4 percent) suggested other low-cost energy conservation measures. Approximateiy one-fourth of renters (24 percent) felt that no improvements were needed. 


\section{DISTRIBUTION}

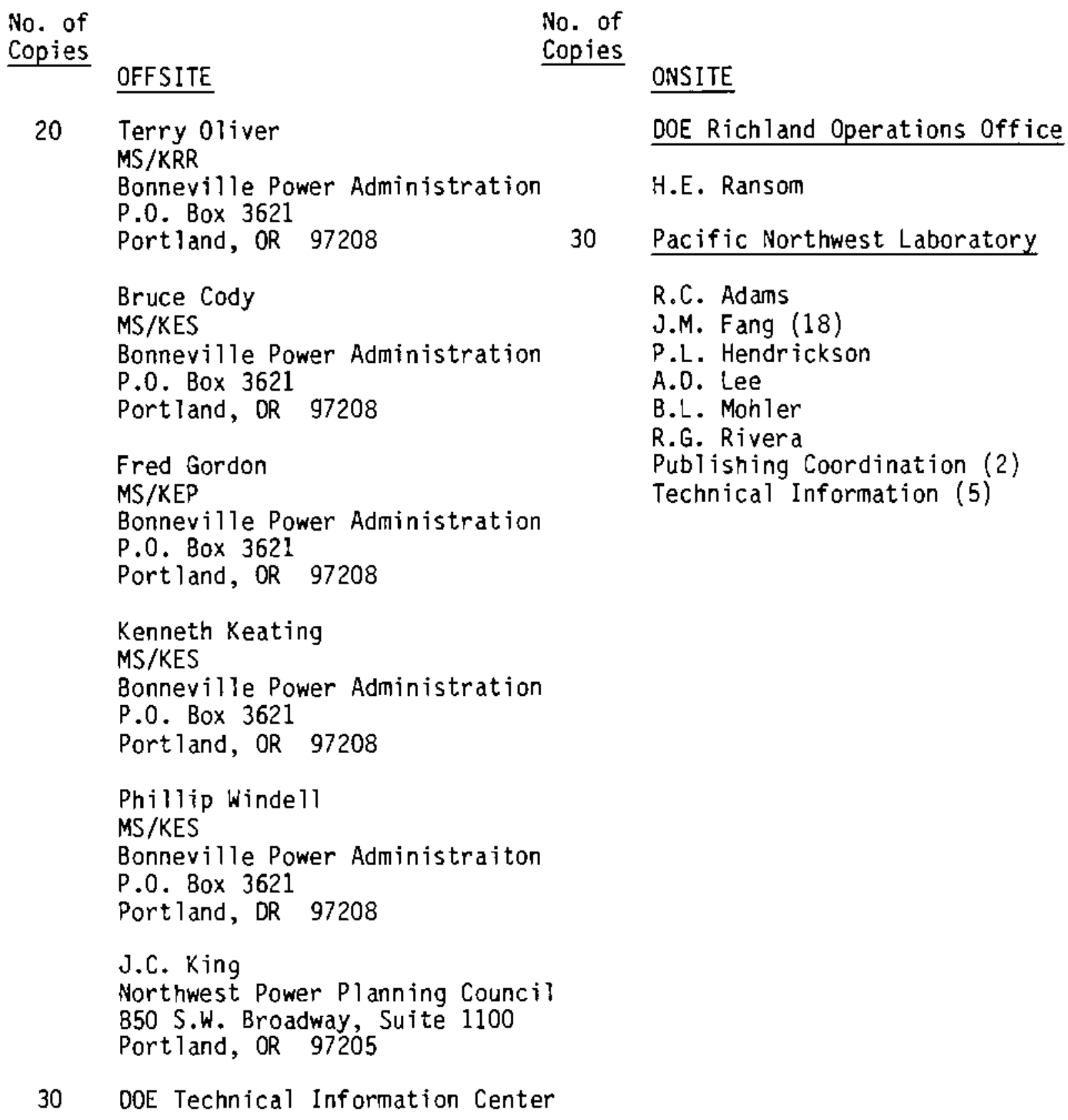

No. of

Copies

OFFSITE

20 Terry 0liver

MS/KRR

Bonneville Power Administration P.0. Box 3621

Port 1 and, OR 97208

Bruce Cody

MS/KES

Bonneville Power Administration

P.0. Box 3621

Portland, OR 97208

Fred Gordon

MS/KEP

Bonneville Power Administration P.0. Box 3621

Portland, OR 97208

Kenneth Keating

MS/KES

Bonneville Power Administration

P.0. Box 3621

Portland, OR 97208

Phillip Windell

MS/KES

Bonneville Power Administraiton

P.0. Box 3621

Portland, DR 97208

J.C. King

Northwest Power Planning Counci?

B50 S.W. Broadway, Suite 1100

Portland, OR 97205

30 DOE Technical Information Center

No. of

Copies

ONSITE

DOE Richland Operations Office

H.E. Ransom

30 Pacific Northwest Laboratory

R.C. Adans

J.M. Fang (18)

P.L. Hendrickson

A.0. Lee

B.L. Mohler

R.G. Rivera

Publishing Coordination (2)

Technical Information (5) 
